\title{
Evrişimli Sinir Ağları ile Mantar Görüntülerinden Mantar Türlerinin Transfer Öğrenme Yöntemiyle Tanımlanması
}

\author{
Bahadır ELMAS*1D \\ ${ }^{1}$ Mimar Sinan Güzel Sanatlar Üniversitesi, Fen Edebiyat Fakültesi, İstatistik Bölümü, 34380, İstanbul, Türkiye
}

(Alınıș / Received: 30.10.2020, Kabul / Accepted: 14.12.2020, Online Yayınlanma / Published Online: 15.04.2021)

\begin{abstract}
Anahtar Kelimeler Mantar türlerini tanımlama, Önceden eğitilmiş ağlar, Transfer öğrenme
\end{abstract}

Özet: Evrişimli sinir ağlarıyla mantarların tanımlanması; hayatî açıdan önemli mantarların koruma altına alınmasında ve mantar kaynaklarının sürdürülebilir yönetim planlarının yapılmasında oldukça önemlidir Ayrıca, zehirli mantarların tespit edilmesinde, mantar yetiştiricileri ile toplayıcıların mantarları tanımlamasında yararlı olabilecek bir problem çözümüdür. Mantar şapkaları döküntü, leke, pul, kuşak, yiv, özgün desen ve renk gibi çok sayıda ayırt edici özelliği sahiptirler. Bu nedenle şapka görüntülerinin Lamel, Yüzük, Sap ve Volva görüntülerine göre tanımlamaya daha çok katkısı olacağı düşünülmüştür. Bunun yanı sıra mevcut veri setleri evrişimli sinir ağları'nı eğitmek için yetersiz veya düzensizdir. Bu tezleri ispat etmek ve çalışmalara katkı sağlamak amacıyla, 18 aile ait 472 sınıfın görüntülerini içeren üç adet yeni veri seti oluşturulmuştur. Düzensiz veri seti 148318, düzenlenmiş Şapka, Lamel, Yüzük, Sap ve Volva görüntülerini içeren veri seti 97450 görüntü içermektedir. Düzenlenerek oluşturulmuş mantar şapka görüntüleri ise 65419 görüntüden oluşmaktadır. Çalışmada 6 evrişimli sinir ağl, transfer öğrenme yöntemi kullanılarak eğitilmiştir. Düzenlenmiş mantar şapka veri setiyle eğitilmiş en başarılı ağın doğruluk oranı \%97.62'dir. Bu veri setinin görüntü sayısı, birinci veri setine göre \%44, ikinci veri setine göre $\% 32$ daha az olmasına rağmen başarı oranı birinci veri setine göre $\% 26.53$, ikinci veri setine göre \%14.5 daha iyidir.

\section{Identifying Species of Mushrooms Through Mushrooms Images by Convolutional Neural Networks with Transfer Learning Method}

\author{
Keywords \\ Identifying species of \\ mushrooms, \\ Pre-trained networks, \\ Transfer learning
}

\begin{abstract}
Identification of fungi by convolutional neural networks; It is very important for the protection of vital mushrooms and for making sustainable management plans of mushroom resources. It is also a problem solution that can be useful in detecting poisonous mushrooms and for mushroom growers and collectors to identify mushrooms. Mushroom hats have many distinctive features such as rash, stain, scale, sash, groove, unique pattern and color. For this reason, it is thought that hat images will be more successful in defining according to Lamella, Ring, body and Volva images. In addition, the available datasets are insufficient or disorganized to train convolutional neural networks. In order to prove these two theses and contribute to the studies, three new datasets containing the images of 472 classes belonging to 18 families were created. The irregular dataset contains 148318 images. the dataset of the edited Hat, Lamella, Ring, Body and Volva images has 97450 images. Mushroom hat images created by editing consist of 65419 images. In the study, 6 convolutional neural networks were trained using the transfer learning method. The accuracy of the most successful network trained with the regulated mushroom hat dataset is $97.62 \%$. Although the number of images of this dataset is $44 \%$ less than the first dataset and $32 \%$ the second dataset. the success rate is $26.53 \%$ better than the first dataset and $14.5 \%$ the second dataset.
\end{abstract}

\section{Giriş}

Mantarlar; çıplak gözle görülebilecek ve elle toplanabilecek büyüklükte, kendine özgü meyve kısımları olan makrofunguslar olarak kabul edilmektedir [1]. Mantarlar yenilebilir ve tıbbi olmak üzere iki gruba ayrılmaktadır [2]. Yüksek besin değerine sahip mantarlar, genellikle gıda ürünü 
olarak tüketilmektedir. Mantarlar B3, B12 vitamini, demir, potasyum, kalsiyum, bakır, selenyum, fosfor, magnezyum, çinko ve manganez gibi birçok mineralleri içermektedir. Bunun yanı sıra riboflavin, niasin, pantotenik ve konjuge linoleik asit kaynağıdır [3]. Protein miktarı et, yumurta ve süt kadar yüksektir ve en iyi D vitamini kaynaklarından biridir [3-5]. Hayvansal kaynaklar dışında D vitamini içeren tek doğal kaynaktır. Mantarların bazı besin değerleri Tablo 1'de verilmiştir [6].

Mantarlar içerdikleri biyoaktif bileşikler nedeniyle birçok hastalığın önlenmesi ve tedavisinde destekleyici ürün olarak da kullanılabilmektedir. Doğadan toplanan çoğu mantar türlerinin antitümör, antioksidan, antimikrobiyal, antiviral ve antialerjik gibi tıbbi yararları olduğu tespit edilmiştir [7].

Tablo 1. Mantarların besin değerleri [6]

\begin{tabular}{cc}
\hline \multicolumn{2}{c}{ Mantarların Besin Değerleri } \\
\hline Enerji & $240-310 \mathrm{kcal} / \mathrm{kg}$ \\
Yağ & $20-30 \mathrm{~g} / \mathrm{kg}$ \\
Protein & $200-250 \mathrm{~g} / \mathrm{kg}$ \\
Karbonhidrat & $500-650 \mathrm{~g} / \mathrm{kg}$ \\
Diyet Lifleri & $220-300 \mathrm{~g} / \mathrm{kg}$ \\
\hline
\end{tabular}

Doğada yabani olarak yetișen 140000'den fazla mantar türü bulunmaktadır [8]. Bunlardan 2500 kadarı yenilebilir olarak tanımlanmıștır [9]. Doğadan toplanan yenilebilir yabani mantarlar, kültür mantarlarına göre çok talep görmektedir. Yabani mantarlara olan bu talep artışı ve ticari potansiyel, mantarları odun dışı orman ürünü alternatifi arasına sokmaktadır $[10,11,12]$. Fazla işgücü gerektirmemesi, iș gücünün ve mantar toplama șeklinin düșük masraflı olması nedeniyle insanlar için geçim kaynağı haline gelmiştir [13]. Fakat bilinçsiz toplayıcılık ve mantar üretim taleplerindeki son yıllardaki aşırı artış, mantarcılıkta sürdürülebilirlik problemlerinin ortaya çıkmasına sebep olmuştur [11]. Özellikle gelişmiş ülkelerde mantara çok fazla talep vardır; bu ülkelerde kişi başına yıllık mantar tüketimi 2.5kg'a kadar yükselmiştir. Şekil 1'de 2005 yılı ile 2017 yılları arasında dünyada mantar tüketim miktarları verilmiştir [14].

Tüketim miktarları, mantara ilginin önümüzdeki yıllarda daha da artacağını göstermektedir. Şekil 2'de verilmiștir [15].

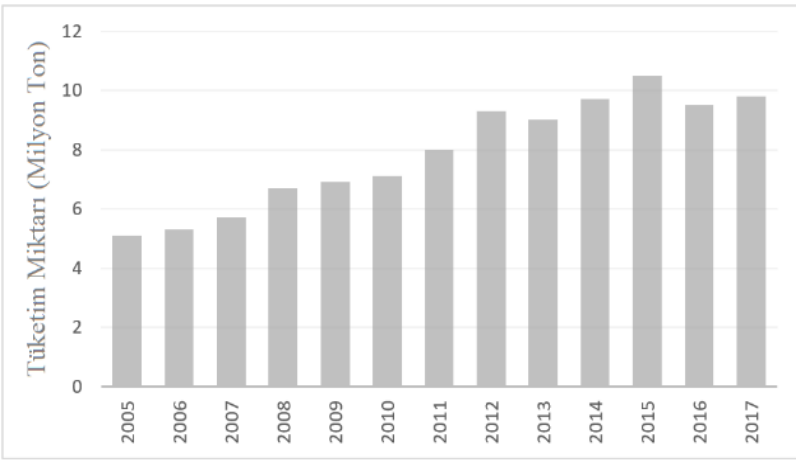

Şekil 1. Dünya'da mantar tüketim miktarları [14]

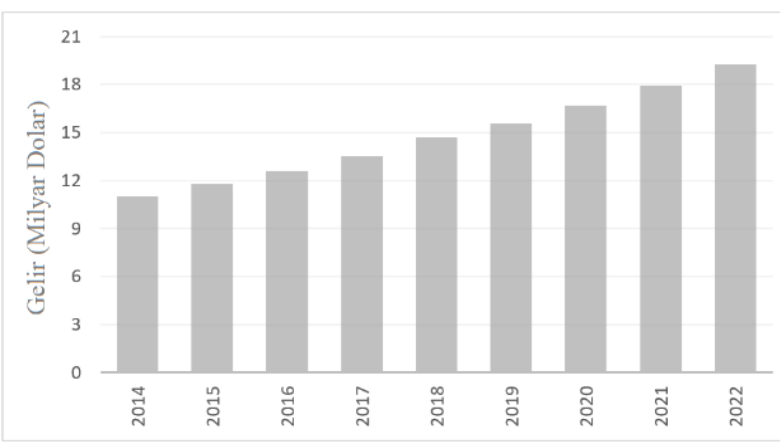

Şekil 2. Dünya'da mantar gelir miktarları [15]

Yaşam açısından çok değerli olan mantarların herkes tarafından tanımlanması önemli bir sorundur. Özellikle mantara dokunmadan ve zarar vermeden görsel olarak tanımlanması insan sağlığı ve mantarlar kaynaklarının sürdürülebilirliği açıdan önemlidir. Mantar türlerini mantar görüntülerinden tanımlama yeteneği, önemli bir sorun olmasına rağmen yeterince ilgi görmemiștir. Bunun nedeni bu alandaki veri yetersizliği veya düzensizliğidir.

Bazı mantar türlerinin yapılarında çok ince farklar olmakla beraber doğada çok sayıda mantar türü bulunmaktadır. $\mathrm{Bu}$ nedenle mantar türlerinin tanımlanması eğitimli ve tecrübeli insanların dahi zorlandığı bir konudur. Mantar türlerinin belirlenmesinde, görme problemleri üzerinde etkileyici sonuçlar veren ve her geçen gün hızla ilerleme kaydedilen derin öğrenme yöntemlerinden evrişimli sinir ağlarını kullanmak yararlı olabilecek bir problem çözümüdür. Bu çalışmadaki görsel tür tanımlaması; mantarların geleceğe taşınmasında, yaşam açısından önemli mantarların koruma altına alınmasında, mantar kaynaklarının sürdürülebilir yönetim planlarının yapılmasında, mantarların zehirli olup olmadığının tespitinde, botanik araştırmalarında, mantarların sınıf veya alt türlerinin belirlenmesinde, mantar yetiştiriciliğinde, mantarların işlenme süreçlerinde, mantar toplayıcıların mantarları türlerine göre sinıflandırmasında yararlı olabilecek bir problem çözümüdür.

Derin öğrenmedeki son gelişmeler sinir ağlarının birçok görsel tanıma görevinde insan performansını geçebildiğini göstermiştir. Derin öğrenme yaklaşımlarının önemli dezavantajı, tatmin edici sonuçlar elde etmek için genellikle çok büyük veri setlerine ihtiyaç duymalarıdır. Örneğin, ImageNet veritabanı, 15000000 'u aşan resim içeren ve 22000 kategoriye ayrılmış bir veri setidir. Dünyada trilyonlarca mantar olup doğada yabani olarak yetişen 140000'den fazla mantar türüne rağmen mantar türü tanımlaması için boyut veya çeşitlilik bakımından eşdeğer bir veri seti yoktur. Bu alandaki, en büyük görsel veri setlerinden mushroomobserver WEB sitesinde yaklaşık 250 bin mantar görüntüsü bulunmaktadır. Bu veri setinde her mantar türüne ait yaklaşık 1 ile 5 arasında görüntü mevcuttur [16]. 2018 FGVCx mantar sınıflandırma yarışmasında 
kullanılan veri setinde ise toplam 1394 mantar türü vardır. Söz konusu veri seti 99.518 adet görüntü içermektedir [17,18]. Kuzey Avrupa mantar türlerinin en yaygın dokuz adet mantar türünü barındıran diğer bir veri setinde ise 6713 görüntü vardır [19]. Bu çalışmada söz konusu bu sorunun çözümüne katkıda bulunmak ve evrişimli sinir ağlarını eğitmek amacıyla yeni, yeterli ve düzenli bir veri seti olușturulmuştur. Söz konusu veri seti bir yılı kapsayan bir süreçte diğer veri setlerinden, doğaseverlerin fotoğraf çekimlerinden ve bu çalışma için çekilmiş fotoğraflardan oluşmaktadır. Oluşturulan veri setinde Lamel, Yüzük, Sap, Volva özelliklede mantar şapkalarını ön planda tutacak şekilde yeniden düzenlenmiştir.

$\mathrm{Bu}$ çalışma bir başlangıç çalışması olup, ilk aşamada oluşturulan mantar veri seti ile önceden eğitilmiş ağları transfer öğrenme yöntemleriyle eğiterek mantar türlerinin tanımlanmasının mümkün olduğunu göstermektir. $\mathrm{Bu}$ çalıșma sonucunda kazanılacak bilgi ve tecrübeler doğrultusunda çalışmanın devamında planlanan proje ile veri setini Türkiye sınırlarını kapsayacak şekilde mümkün olduğunca büyütmektir. Bu veri setiyle de mantar görüntülerinden mantar tanımlaması yapabilecek yüksek çözünürlükte veri girişine sahip, söz konusu göreve özgün bir ağ tasarlamaktır. Yine proje kapsamında mantar alt türlerinin tanımlamasını yapabilecek ikinci özgün bir ağ tasarımının yapılması planlanmaktadır. Her iki ağ tasarımı herkesin ulaşabileceği uygulamalar haline getirilerek oluşturulan veri setiyle birlikte kamuya açlacaktır.

Image-CLEF Challenge 2013'te bitkilerin tanınması için yapılan çalışmalarda yaprak verilerin yanı sıra bitkinin diğer kısımları da kullanılmaya başlamıştır. Farklı ekipler, bitkinin farklı kısımlarının görüntüleriyle bitki türlerini tanımlamak için algoritmalar ve programlar geliştirilmiştir [20, 21]. 2014 yılına kadar, algoritmaların çoğu ScaleInvariant Feature Transform veya Speeded-Up Robust Features gibi noktaların tespit edilmesi ve karakterizasyonuna, Fourier veya Local Binary Pattern dönüşümlerinden elde edilen renk bilgilerine ve bag-of-word yaklaşımlarına dayanmaktaydı [2224]. ImageCLEF $2015^{\prime}$ ten itibaren ise bitkilerin sınıflandırılması veya özelliklerin çıkarılmasında derin öğrenme yaklaşımları kullanılmaya başlanmıştır [25].

M. Sulc ve arkadaşlarının LifeCLEF 2014'da bitki türlerinin fotoğraflardan otomatik olarak tanınmasına yönelik önceden eğitilmiş ResNet152'yi kullanmışlar ve \%50 ile \%60 arasında başarı elde etmişlerdir [26]. N. Sunderhauf ve arkadaşlarının LifeCLEF 2015'te Fransa'dan 500 farklı ot, ağaç ve eğreltiotu türünden alınan 47000'den fazla kök, yaprak, meyve, çiçek ve dal deseni görüntülerini kullanarak Evrişimli sinir ağları ile sınıflandırma yapmışlar ve ortalama \%25 başarı elde etmişlerdir
[27]. J. Champ ve arkadaşları LifeCLEF 2015'de Batı Avrupa'da yaşayan ağaç, ot ve eğreltiotu türüne ait 1000 adet türün çok sayıda çiçek, yaprak, meyve, kök ve dal görüntülerini toplamışlardır. Çalışmalarında evrişimli sinir ağlarını kullanarak sınıflandırma yapmışlar ve \%58 başarı oranı elde etmişlerdir [28]. H. Goeau ve arkadaşları LifeCLEF 2017'de yaptıkları çalışmada AlexNet, GoogLeNet, ResNet, VGGNet gibi birçok mimariyi kullanarak çiçek, meyve, tüm bitki görüntüsü, yaprak, dal deseni, üzerine yaptıkları çalışmada \%48 ile \%95 arasında değişen başarı oranları elde etmişlerdir [29]. LifeCLEF'de bitki sınıflandırmasının yapıldığı bu çalışmalarda derin öğrenme yaklaşımları kullanılmıştır.

Mantar tanımlama alanında yapılan çalışmalar ise şu şekildedir; A. Masoudian ve K. A. McIsaac, Mantar hasat robotunun mikrobik veya mekanik kaynaklı mantar hasarını tespit etmek amacıyla hızlı ve tahribatsız bir yöntem için Destek Vektör Makinesi yöntemini uygulamıșlardır. Çalıșmalarında \%90'ın üzerinde doğruluk oranı elde etmişlerdir [30]. A. Subramaniam ve B.J. Oh yaptıkları çalışmada, temel bileșen analizi algoritmasını kullanarak yenilebilir mantarları yenilemeyen mantarlardan ayırt etme yöntemini önermişlerdir. Önerilen yöntemin başarı oranı, eğitim görüntülerinin sayısı bağlı olarak \%85 ile \%96 arasındadır [31]. Kyung-Jong Kim ve arkadaşları evrişimli sinir ağlarını kullanarak mantar tarlalarında yetiştirilen mantarların haşere durumunu analiz etmek için bir sistem önermişlerdir. Çalışmayı mantar hastalıkları ve zararlıları hakkındaki özel verilerden elde edilen yaklaşık 1500 mantar görüntüsü ile gerçekleştirmişlerdir [32]. A. J. Olpin yaptığı çalışmada tarım mantarlarını sinıflandırmak ve tespit için iki takım deney yapmıştır. Sınıflandırma için yaptığı ilk deney setinde standart bir evrişimli sinir ağlarını kullanmış, \%87.5 ile \%88.9 arasında doğruluğa ulaşmıştır. İkinci deney setinde ise Bölge Tabanlı Evrişimli Sinir Ağını (Region-Based Convolutional Neural Network) kullanmış, \%92.1 doğruluk elde etmiştir [33]. R. F. Rahmat ve arkadaşları zehirli mantarları tanımlamak için K-En Yakın Komşu Algoritmasını önermișlerdir. Tanımlama işleminden önce, görüntü gri ölçeklendirme, görüntü kenarı ve eşikleme, görüntü bölümleme ile özellik çıkarma işlemi kullanılarak mantar görüntüleri ön işlemden geçirmişlerdir. Sistemi test etmek için 40 mantar görüntüsü kullanılmıș, zehirli mantar tanımlamasında sistemin doğruluk oranı \%90 olarak bulmuşlardır [34]. Wibowo ve arkadaşları, Karar Ağacı (C4.5), NaïveBayes ve Destek Vektör Makinesi yöntemlerini kullanarak Agaricus ve Lepiota ailesinin mantar verileri sınıflandırmışlardır. Test sonuçları, C4.5 algoritmasının Support Vector Machine (SVM) ile \%100 oranında aynı doğruluk seviyesine sahip olduğunu göstermiş ancak hız açısından C4.5 algoritmasının SVM'den daha hızlı olduğunu tespit etmişlerdir [35]. M. Wulandari ve arkadaşları, zehirli mantarları belirlemek amacıyla geri yayılımlı bir sinir 
ağını kullanmışlardır. 1020 eğitim verisi üzerinde özellik çıkarmada, renk için 3D Renk Vektörü Niceleme ve form çlkarma işlemi için $\mathrm{Hu}$ Moment yöntemlerini kullanmıșlardır. Araștırmanın sonucunda, \%89.71 doğrulukla mantar türlerini tespit etmişlerdir [36]. A. Anil ve arkadaşları, Agaricus ve Bisporus mantarlarının açık atmosferde çevreyle reaksiyona girme ve kahverengi renkli bir pigment geliştirme eğiliminden yola çıkarak mantarda tazeliğin belirlenmesi için bilgisayar tabanlı görme yöntemi önermișler. SVM sınıflandırıcısının \%80 doğrulukla mantarın tazeliğini belirlediği sonucuna varmışlardır [37]. P. Maurya ve N. P. Singh yenilebilir ve zehirli mantarları ayrt etmek için makine öğrenme yaklaşımına dayanan doku özelliğini kullanarak mantarın sınıflandırılması için bir SVM sınıflandırıcıyı önermişler ve önerdikleri yaklaşımın performansını \%76.6 olarak bulmuşlardır [38].

\section{Materyal ve Metot}

\subsection{Evrişimli sinir ağları ve transfer öğrenme}

Derin sinir ağları bilgisayarlı görme, konuşma tanıma ve robotik içeren için birçok yapay zekâ uygulamasında yaygın olarak kullanılmaktadır. Derin sinir ağlarının sıkça tercih edilen bir şekli ise çoklu evrişimli katmanlardan oluşan evrişimli sinir ağlarıdır [39]. Evrișimli sinir ağları, ızgara benzeri bilinen bir topolojiye sahip veriyi işlemek için kullanılan bir tür sinir ağı olan derin öğrenme yöntemidir [40]. İleri beslemeli mimariye sahiptir ve tamamen bağlı katmanlara sahip ağlara kıyasla daha iyi genelleme yapar [41, 42]. Daha çok örüntü tanıma, sınıflandırma, sinyal ișleme, sözlük, tıp, finans ve savunma sanayinde kullanılmaktadır. Evrişimli sinir ağları çoğunlukla Şekil 3'teki gibi Convolution, Rectified Linear Unit (ReLU), Pooling ve Fully Connected Layers (FC) katmanlarından oluşur [41, 43-46].
Yeni bir evrişimli sinir ağı yaratmanın ve eğitmenin ilk adımı ağ mimarisini tanımlamaktır. A $\breve{g}$ mimarisi, dâhil edilen katmanların türlerine ve sayılarına bağlı olarak değișebilir. Dâhil edilen katmanların türleri ve sayısı, uygulamaya veya verilere bağlıdır. Uygulamada kategorik yanitlar varsa, bir softmax ve sınıflandırma katmanına sahip olunmalıdır. Yanıt sürekli ise; ağın sonunda bir regresyon katmanı bulunmalıdır. Yalnızca bir veya iki evrișimli katmana sahip küçük bir ağ, az sayıda gri tonlamalı görüntü verisini öğrenmek için yeterli olabilir. Diğer taraftan, milyonlarca renkli görüntü içeren karmaşık verilerde, daha karmaşık ağlara ihtiyaç duyulmaktadır [45]. Evrişimli sinir ağlarında Şekil 3'te gösterildiği gibi ilk katmanlarda verilen girdi üzerinde, filtreler yoluyla özellik çıkarımı gerçekleștirilir. Aynı zamanda bir yandan hesaplama maliyetini düşürmek diğer yandan ise girdiden öğrenilen özelliklerin özet bilgisini diğer katmanlara aktarmak amaciyla boyut düşürme fonksiyonları kullanılır. Daha sonra girdiden elde edilen bu özellikler tek boyutlu bir vektör haline getirilir ve tam bağlantılı katman veya katmanlara girdi olarak verilip, sınıflandırma işlemi gerçekleştirilir. Ağın filtreler ve ağırlıklar altındaki performansı, bir kayıp fonksiyonu ile hesaplanır ve öğrenilebilir parametreler yani filtreler ve ağırlıklar geri yayılım yoluyla kayıp değerine göre güncellenir [42]. Evrişimli sinir ağlarının her biri farklı mimarî kullanarak eğitim işlemi gerçekleştirmektedir. $\mathrm{Bu}$ çalışmada kullanılan evrişimli sinir ağları; AlexNet, ResNet18, ResNet50, ResNet101, VGG16, VGG19'dur [47-50]. Tablo 2'de söz konusu ağların katman, derinlik, parametre sayısı, görüntü giriş boyutları ve ağ mimarileri verilmiştir.

Bazı evrişimli sinir ağlarının eğitilmesi, ağın karmaşıklığı ya da veri setinin büyüklüğü nedeniyle standart bilgisayar işlemcilerinde gerçekleştirmek oldukça zordur. Bu nedenle güçlü grafik işleme birimlerine ihtiyaç duyulur. Uzun süren eğitimler sonucunda eğitilmiş birçok modelden problem için

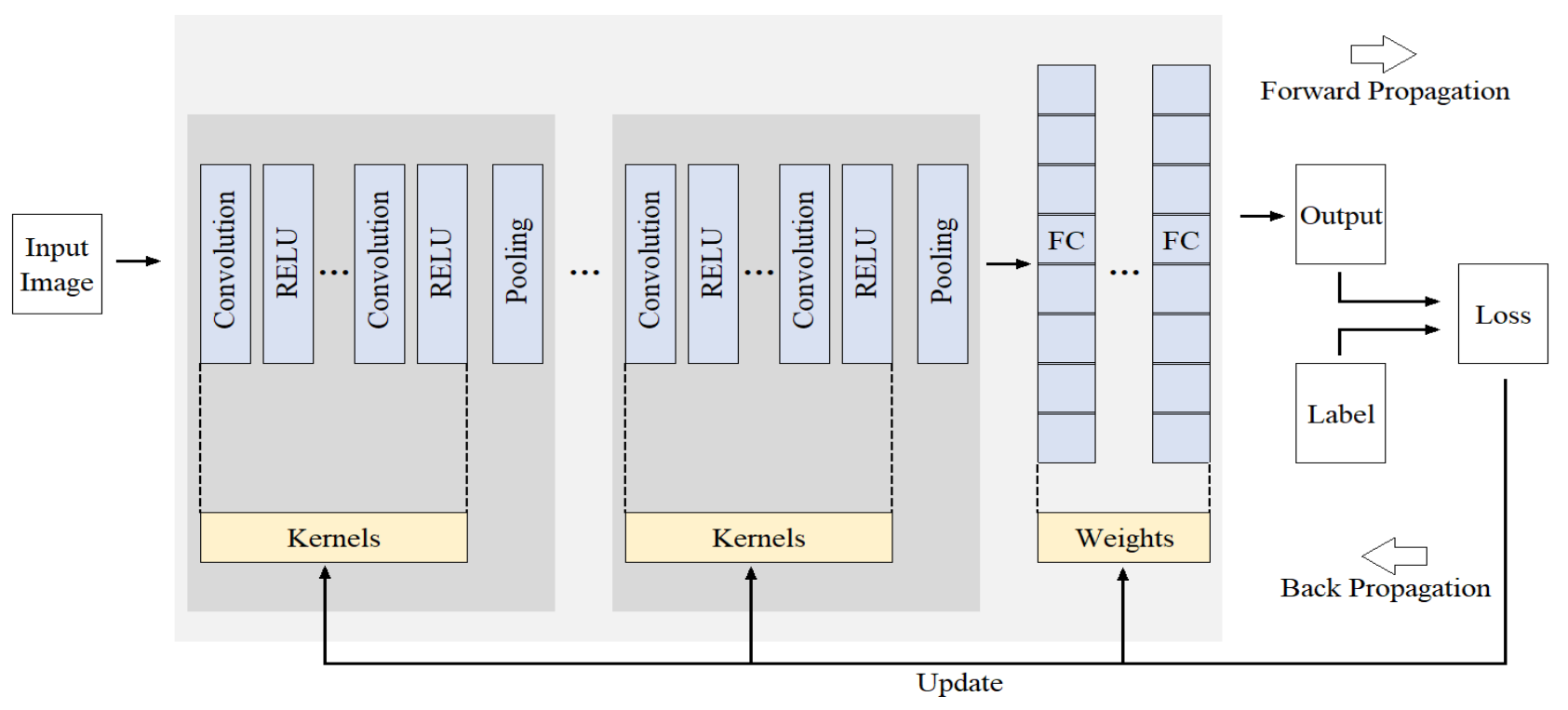

Şekil 3. Evrişimli Sinir Ağlar 
Tablo 2. Ağların derinlik, katman, parametre sayısı, resim giriș boyutu ve mimarileri

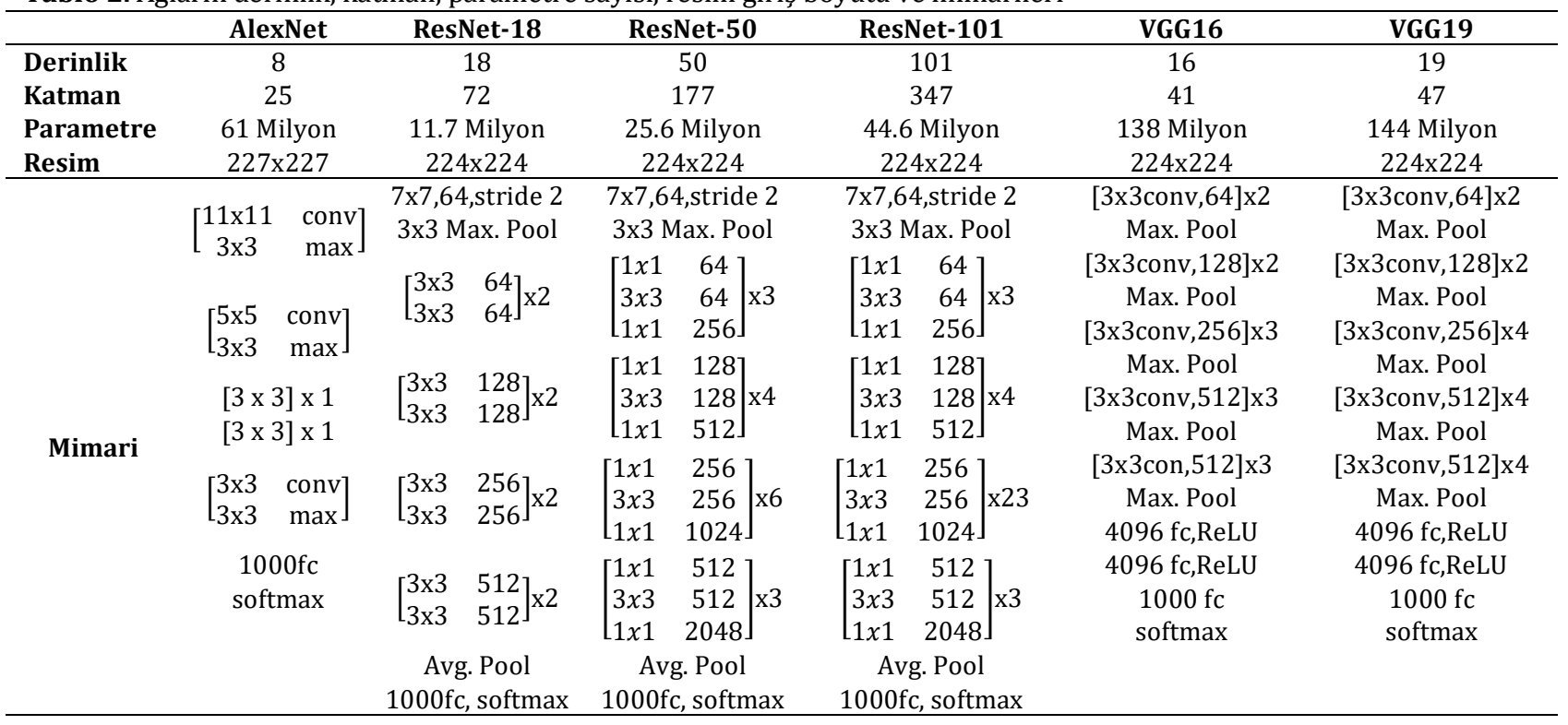

uygun bir model seçilerek problemin çözümünde kullanılabilir. Eğitilmiş bir ağın, ilgili ikinci bir görevde yeniden tasarlandığı, hızlı ilerleme ve gelişmiş performans sağlayan bu makine öğrenmesi tekniğine transfer öğrenme denir. Transfer öğrenme; ağın eğitilmesi için yeterli zaman yok ve donanım yetersizse, ne kadar veri olduğuna dair endişelenmeden, bir derin öğrenme modeli oluşturmanın en hızlı ve en kolay yoludur [51-53]. Geleneksel makine öğrenme teknikleri, her görevi sıfırdan öğrenmeye çalışırken, transfer öğrenme teknikleri, önceki görevlerden elde ettiği bilgileri yeni bir görevi öğrenme hedefine aktarır [53]. Öğrenilen niteliklerin taşınabilir olması derin öğrenmeyi eski ve sığ öğrenme yaklaşımlarından ayıran en önemli avantajlarından biri olup derin öğrenme yöntemini küçük veri problemlerinde etkin yapar [54].

Evrișimli sinir ağlarının giriş ve ara katmanları genellikle kenar, doku, desen, gibi üst seviye özellikleri öğrenirken son katmanları daha spesifik özellikleri öğrenir. Bu yüzden giriş ve ara katmanlar korunurken son katman probleme uygun şekilde tasarlanıp, mevcut veri setiyle eğiterek hılı bir şekilde yeni bir model elde edilir [55]. Veri ve hedef görev, orijinal modelin üzerinde çalıştığı veri ve hedef görevle benzerlik gösteriyorsa, bu yaklaşım en iyi sonucu verir. Bununla birlikte, bir modeli sıfırdan eğitmek için yeterli veri varsa ve görevler o kadar yakın olmasa da, önceden eğitilmiş bir model kullanarak parametreleri başlatmak, rasgele başlatmadan daha iyi sonuçlar verebilir [56]. Ayrıca sahip olunan veri problemli ve miktarı yetersiz ise bu veri için tasarlanmış özel model, önce genel bir görev için hazırlanmış büyük bir veri kümesi kullanılarak eğitildikten sonra mevcut veri ile eğitilebilir. Bu yöntemde aktarılan şey temel olarak parametrelerin başlangıç değerleridir. Ağırlıkları rastgele başlatmak yerine önceden eğitilmiş bir ağl kullanarak başlatmak; ağın öğrenmede iyi bir başlangıç yapmasını, öğrenme gelişiminin daha hızlı olmasını ve daha yüksek performans elde etmesini sağlayarak yakınsamayı hızlandırır. Ayrıca yeterli veri olmadığı durumlarda, transfer öğrenme ağı așırı öğrenmeden koruyarak eğitmek için iyi bir seçenektir. Şekil 4'teki gibi Tam Bağlı katman dışındaki tüm katmanları aktarmak en yaygın transfer öğrenme türüdür. Bu çalışmada da bu yöntemin kullanılması tercih edilmiştir [51-53].

Ayrıca önceden eğitilmiş bir ağın ilk n katmanını bir hedef ağa aktarıp geri kalan katmanları rastgele başlatmak da mümkündür. Aktarılan kısmın, ilk katmanlar olması da gerekmez. Görevler aynı fakat girdi verilerinin türü biraz farklıysa, son katmanları da aktarmak mümkündür.

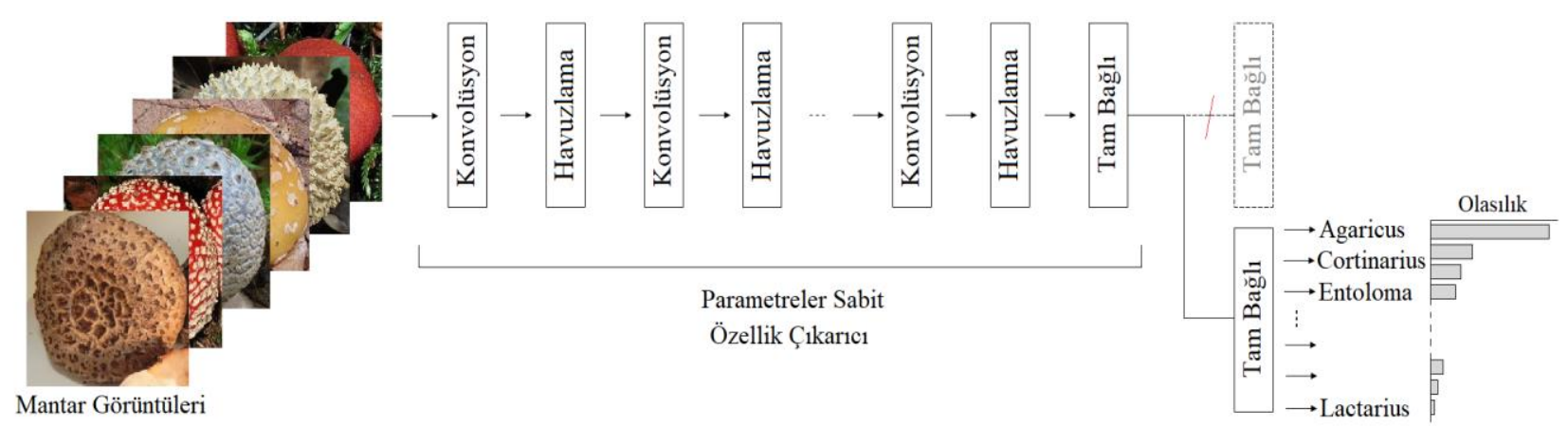

Şekil 4. Tam Bağlı katmanların probleme göre tasarımı. 


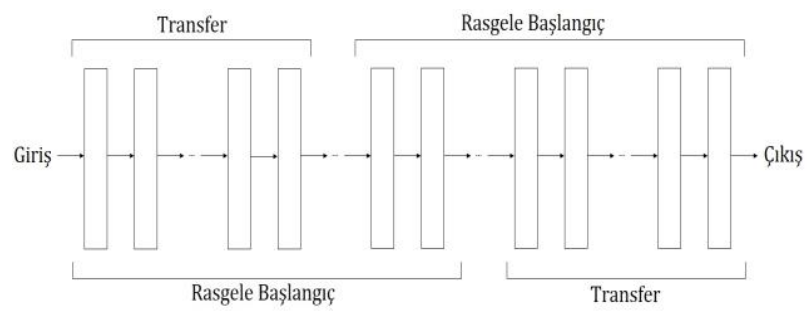

Şekil 5. İlk ve son katmanların transfer modeli

Transfer öğrenme pek çok görev için kullanabilir. Ancak bir modeli bașka bir modele aktarmak her zaman mümkün değildir. Veri türünün ve görevinin oldukça farklı olduğu durumlar bu kapsama girer. Transfer öğreniminin uygulanamayacağı bir başka durum, özellikleri aktarılacak model ile aktarılan modelin mimarisindeki uyumsuzluk durumudur. Farklı mimarilere sahip modeller arasında bilgi aktarımını sağlayan teknik model ise Şekil 6'da verilen damıtmadır. Önceden eğitilmiş bir modelin damıtılması; yeni modeli, doğrudan veriler üzerinde eğitmek yerine önceden eğitilmiş modelin çıktılarını taklit edecek şekilde eğitilmesidir. Bu yaklaşım özellikle kaynak modelden daha küçük bir modelin eğitilmesinde verimlidir.

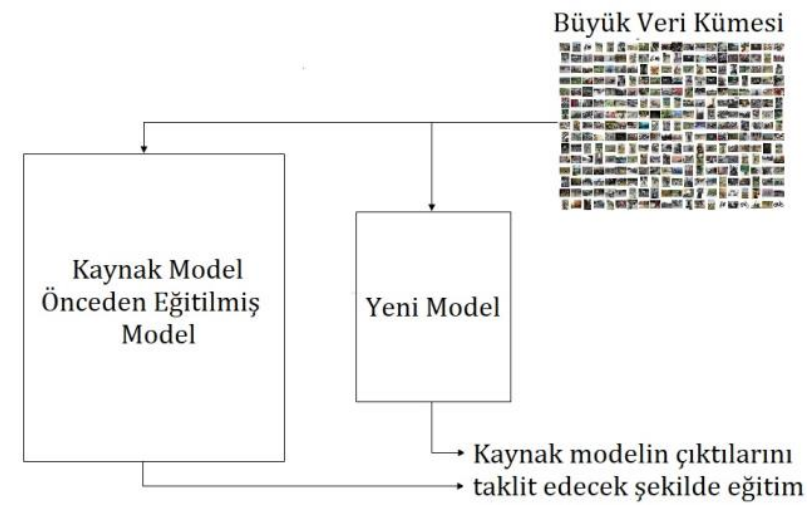

Şekil 6. Eğitilmiş bir modelin damıtılması

Mantar sınıflandırılması, ImageNet yarışmasından farklı bir problem olup daha spesifik bir problem çözümüdür. $\mathrm{Bu}$ yüzden çalışma için oluşturulan mantar veri seti ile yarışmada kullanılan ağların eğitilmesi gerekir. Ağların giriş katmanından sınıflandırma katmanına kadarki ara katmanlar, Şekil 4'teki gibi korunmuştur. Veri seti ağların giriş katmanından verilmiştir. Çalışmada kullanılan ağlar 1000 sınıflandırma yaparken bu çalışma 18 sinıflandırma yapmaktadır. $\mathrm{Bu}$ nedenle ağların sınıflandırma katmanları Şekil 4'teki gibi 18 sınıflandırma yapacak şekilde tasarlanmıştır. Ağlardan AlexNet, VGG16 ve VGG19'da havuzlama katmanında maksimum havuzlama yöntemi kullanılırken, ResNet-18, ResNet-50, ResNet-101 ağlarında ise maksimum ve ortalama havuzlama yöntemi kullanılmıştır. Çalışmada kullanılan ağlar oluşturulan veri setiyle MATLAB ortamında eğitilmiştir (MATLAB R2019a). Eğitimde kullanılan bilgisayarın işletim sistemi 64 bit, işlemcisi Intel(R) Core(TM) i7-7820HQ CPU @ 2.90 GHz, RAM'i 16 GB olup ekran kartı Radeon Pro 560'dır.

\subsection{Veri setinin toplanması}

Mantarlar dünya üzerinde çok fazla tür ve alt tür barındırdığından fiziksel görüntüleri birbirine çok benzemektedir. Çıplak gözle birbirinden ayırt edilemeyen türler vardır. $\mathrm{Bu}$ türler ancak laboratuvarlarda testlerle tayin edilmektedir. Mantarların tanımlanmasında yaygın kullanılan mantar bölümleri Şekil 7'de verilmiştir.

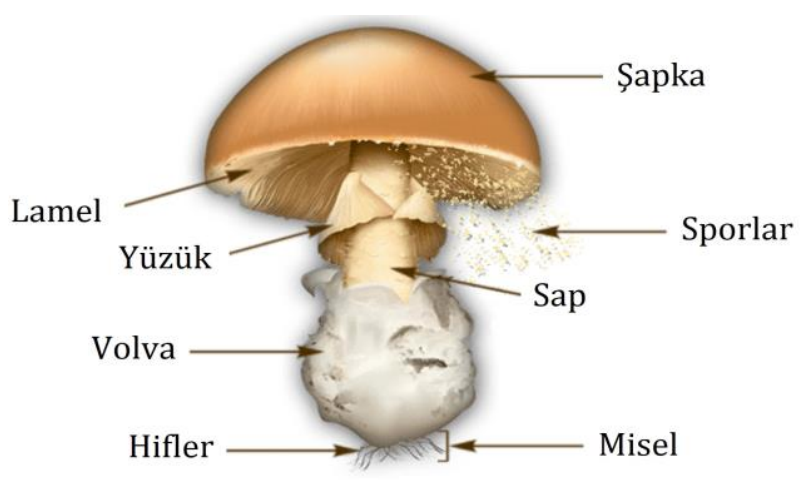

Şekil 7. Mantar bölümleri

Mantarlarda şapka mantarın en üstteki bölümüdür. Şapka, mantar türünün belirlenmesi, başka bir tür ile karşılaştırılması açısından çok önemli ayırt edici özellikleri taşımaktadır. Mantarlarda dokuz adet şapka türü vardır. Bunlara ait görseller Şekil 8'de verilmiştir.

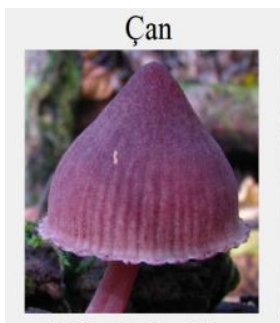

Göbeği Oyuklu

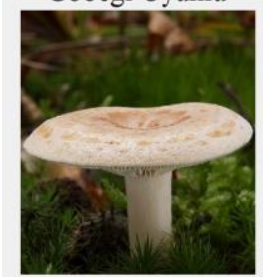

Yumurta

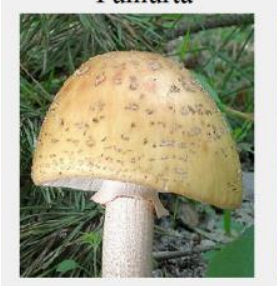

Konik

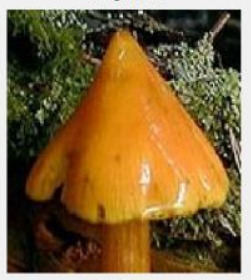

Düz

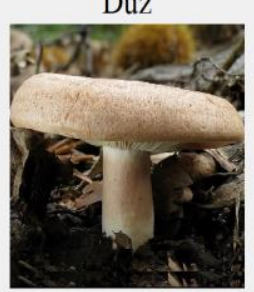

Merkezi Çentik

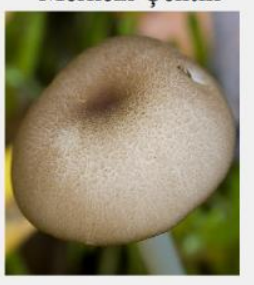

Yarım Küre

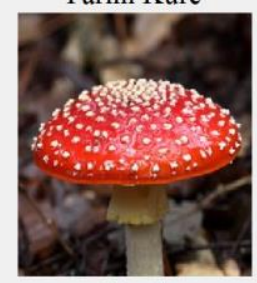

Huni

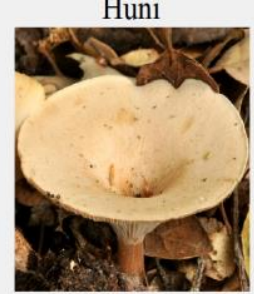

Memeli

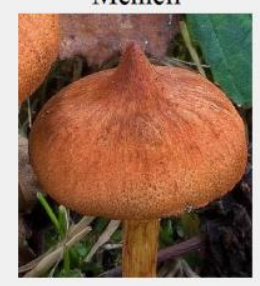

Şekil 8. Mantarlarda şapka çeşitleri

Şapka altındaki yapılar Lamel olarak adlandırılır. Mantarlarda Şekil 9'da verildiği gibi farklı görünümde altı çeşit Lamel vardır. Lamellerin dokusu ve görünümü mantar türlerinin belirlenmesinde önemli ayırt edici bir özelliktir. 


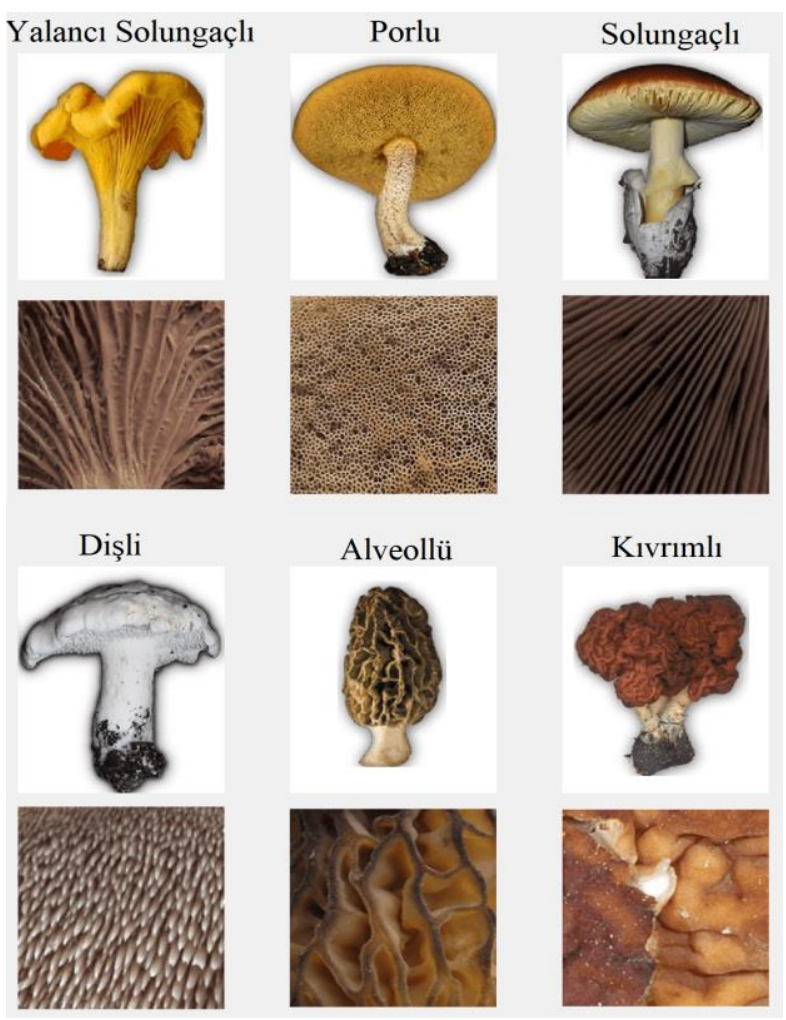

Şekil 9. Mantarlarda lamel çeşitleri.

Mantarların gelişimlerini tamamladığı koruyucu zar, yırtıldıktan sonra mantarın sap bölümüne yapışarak Şekil 10'daki gibi yüzük görüntüsünde bir yapı oluştururlar. Yüzük, tür tayininde bir seçenektir. Fakat çeşitli çevre şartları nedeniyle saptan ayrılabilir veya eriyerek yok olabilirler.

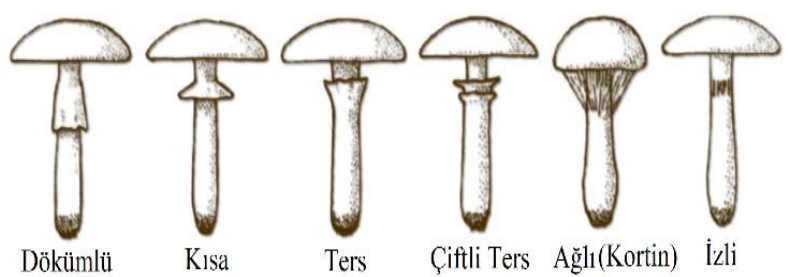

Şekil 10. Mantarlarda yüzük çeşitleri.

Koruyucu zarflar bazen yırtılarak Şekil 11'deki gibi Sap'ın yaşam alanı ile birleştiği yerde bir kılıf olarak kalabilirler. $\mathrm{Bu}$ yapılar Volva olarak adlandırılır. Volva bazı mantarlar için karakteristik bir özelliktir ve ilk bakışta mantar cinsinin belirlenmesinde yardımcı olabilir.
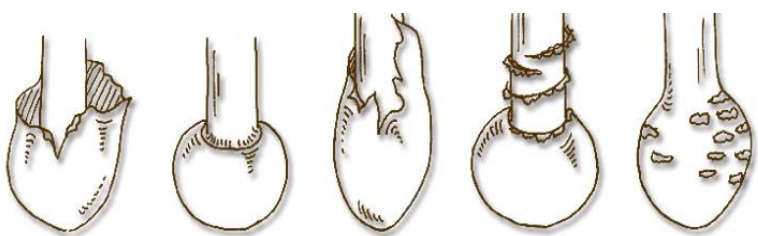

Açık Volva Kapsül Volva Kapalı Volva Yüzüklü Kapsül Pullu Kapsül

Şekil 11. Mantarlarda volva çeşitleri.

Mantarlardaki Sap'ın dokusu, rengi, yüzüklü ve/veya volvalı olup olmaması tür tayininde belirleyici bir özellik olarak kullanılabilir. Mantarlarda altı adet Sap çeşidi vardır; bunlar Şekil 12'de verilmiştir.

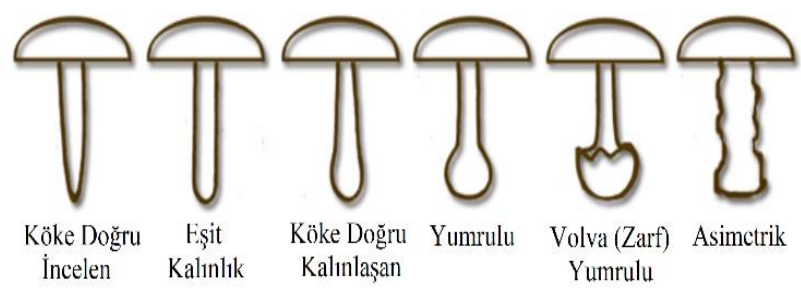

Şekil 12. Mantarlarda sap çeșitleri.

Bunların yanı sıra Hifler, Misel ve Sporlar bazı cins mantarların belirlenmesinde karakteristik özelliklerdir. Fakat bu yapılar yaşam alanının altında veya laboratuvar ortamında görülebileceği için bu çalışmada ayırt edici bir özellik olarak kullanılmamıştır. Çünkü bu çalışma mümkün olduğu kadar mantara dokunmadan veya zarar vermeden mantarların fotoğraflanabileceği bölümlerinden yola çıkılarak tanımlama yapmayı amaçlamaktadır.

Yukarıda belirtilen mantarların tanımlanmasında önemli rol oynayan mantar bölümlerini içeren bir veri seti oluşturmak amacıyla çok sayıda veri seti, doğaseverlerin fotoğraf çekimleri ve yayınları gözden geçirilmiştir. Bunun yanı sıra doğada karşılaşılan mantarlarda fotoğraflanarak oluşturulan veri setine eklenmiștir. İncelenen veri setleri;

- 2018 FGVCx mantar sınıflandırma yarıșmasında kullanılan veri kümesinde toplam 1394 mantar türü vardır. Söz konusu veri seti 99518 adet görüntü içermektedir. [17,18].

- Kuzey Avrupa mantar türlerinin en yaygin dokuz tanesini barındıran diğer bir veri setinde ise 6713 görüntü vardır [19].

- mushroomobserver WEB sitesinde yaklaşık 250 bin mantar görüntüsü bulunmaktadır. Her mantar türüne ait yaklaşı 1 ile 5 arasında görüntü mevcuttur [16].

- first-nature WEB sitesinde 700 'den fazla mantarın görüntü ve açıklamaları bulunmaktadır [57].

- mushroom.world WEB sitesi 139 adet mantar türüne ait görüntüleri içermektedir [58].

- Guillaume Eyssartier ve Pierre Roux tarafından yayınlanan Le Guide Des Champignons kitabında Fransa ve Avrupa'daki 3000 türü ait 1500 'den fazla fotoğraf yer almaktadır [59].

- Borgarino ve Christian Hurtado tarafindan yayınlanan Le Guide Des Champignons kitabında ise 1200 'den fazla türün 900 fotoğrafı vardır [60].

Çalışma için veri seti oluşturmak amacıyla yukarıda bahsedilen veri setleri ve kaynakları incelenirken karşılaşılan en önemli problem mantar görüntülerinin Şekil 13'teki gibi birçoğunun mantar tanımlamaya katkıda bulunmak yerine tanımlamayı zora sokacak mesafeden veya açıdan fotoğraflanmasıdır. 


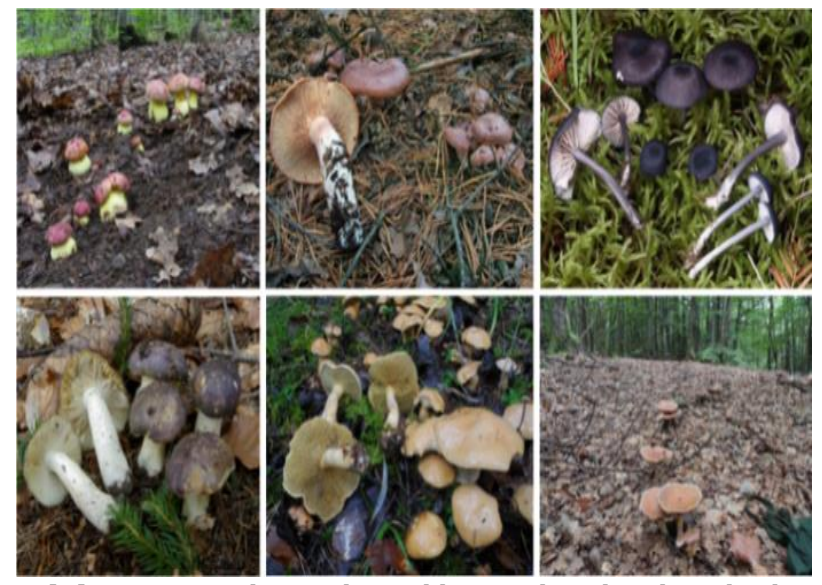

Şekil 13. Veri setleri ve kaynaklar incelenirken karşılaşılan mantar görüntüleri.

Mantar toplayıcıların, araştırmacıların veya doğaseverlerin mantarı ilk gördüğünde gözlerine çarpan mantarın Şapka, Sap, Yüzük, Lamel ve Volva bölümleridir. Özellikle mantarı koparmadan tanımlamak hem sağllk hem de mantarlara zarar vermeme açısından önem arz etmektedir. Bu nedenle veri seti oluşturulurken Şekil 14'teki gibi öncelikle mantarın yukarıdan veya karşı cephesinden çekilen fotoğraflar elde edilmeye çalışılmıştır. Bu işlem yapılırken Şekil 13'teki gibi fotoğraflar kırpma işlemiyle düzenlenmiștir. Böylelikle mantarların Şapka, Sap, Yüzük ve Volva bölümlerinin ön planda olduğu görüntüler veri setine eklenmiştir.
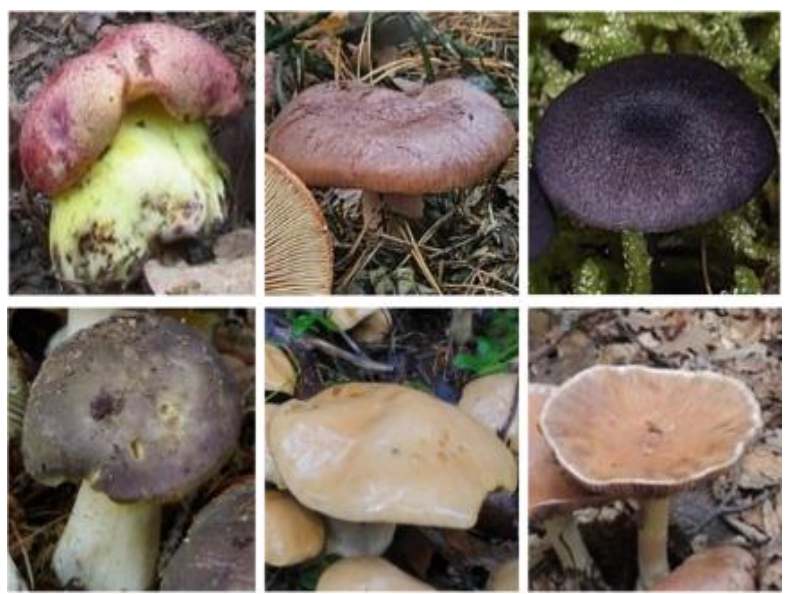

Şekil 14. Düzenlenmiş mantar görüntüleri

Bunun yanı sıra mantarların kesilmesi durumunda görülen ve mantarların tanımlanmasında önemli rol oynayan Lameller de Şekil 15'teki gibi fotoğraflardan kırpılıp düzenlenerek veri setine eklenmiştir.

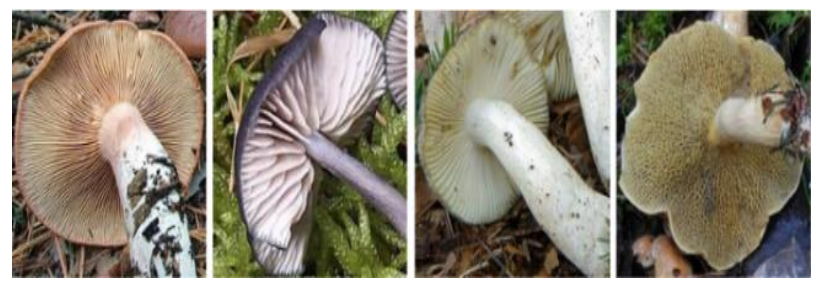

Şekil 15. Düzenlenmiş lamel görüntüleri
Bu şekilde elde edilen fotoğraflar Sap, Yüzük ve Volva bölümlerinde ön plana çıkarması nedeniyle mantar tanımlanmasına önemli katkılar sunmaktadır. Veri setinin oluşturulduğu bu süreçte gözden geçirilen görüntü sayısı 148318 adettir. Fotoğraflar gözden geçirilirken mantar şapkalarının tanımlamada daha ön plana çıkacak özellikler taşıdığı gözlemlenmiştir. Şekil 16'daki gibi şapka üzerindeki döküntü, leke, pul, kuşaklar, yivler, mantar türüne özgü desenler ve renkler bunda önemli rol oynamaktadır.

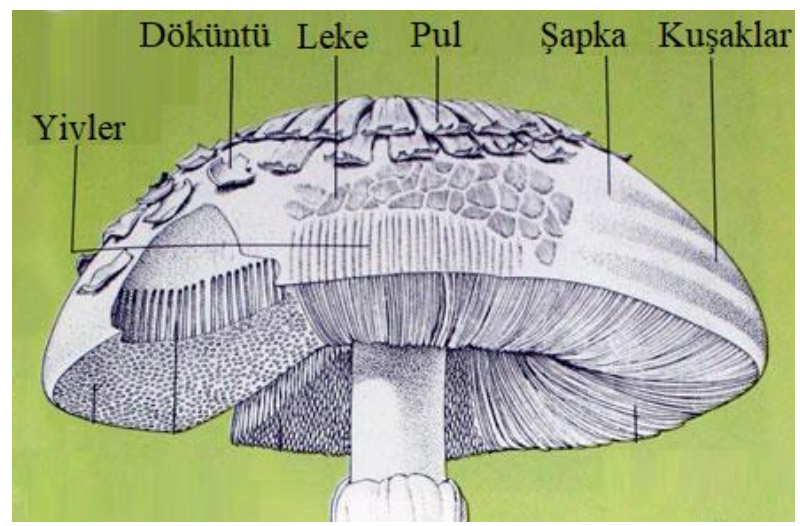

Şekil 16. Mantar şapkası üzerindeki ayırt edici özellikler.

Sadece Şapka, Lamel, Yüzük ve Sap bölümlerinden oluşan fotoğrafların geniş açıdan çekilmiş fotoğraflarına göre mantar tanımlamada daha yüksek performans gösterdiğini ispatlamak, ayrıca mantar şapkalarının tanımlamada daha ayırt edici özellik taşıdığını göstermek amacıyla üç adet veri seti oluşturulmuştur. Birinci veri seti; mevcut veri setleri, doğaseverlerin fotoğraf çekimleri ve çeşitli yayınlardan elde edilen 148318 görüntüden oluşmaktadır. Görüntüler kaynaklardan alınarak düzenlenmeden oluşturulan veri setine eklenmiştir. İkinci veri seti; birinci veri setindeki görüntülerden kesilerek düzenlemiş Şapka, Lamel, Yüzük, Sap ve Volva bölümleridir ve görüntü sayısı 97450 adettir. Üçüncü veri seti ise özellikle mantar şapkalarının ön planda olduğu, düzenlenmiş görsellerden oluşmaktadır. Tablo 3'te mantar şapkalarından oluşan 18 adet mantar ailesinin veri seti gösterilmektedir. Veri setinde 18 aile ile bu ailelere ait 472 sınıftan oluşmaktadır. Toplanan görüntü sayısı 65419 'dur.

Tablo 3. Mantar şapka görüntülerinden veri seti

\begin{tabular}{cccccc}
\hline $\begin{array}{c}\text { Bilimsel } \\
\text { Adı }\end{array}$ & $\begin{array}{c}\text { Snf. } \\
\text { Say. }\end{array}$ & $\begin{array}{c}\text { Sör. } \\
\text { Say. }\end{array}$ & $\begin{array}{c}\text { Bilimsel } \\
\text { Adı }\end{array}$ & $\begin{array}{c}\text { Snf. } \\
\text { Say. }\end{array}$ & $\begin{array}{c}\text { Gör. } \\
\text { Say. }\end{array}$ \\
\hline Agaricus & 30 & 2890 & Lepiota & 12 & 2168 \\
Amanita & 57 & 4124 & Lycoperdon & 9 & 3020 \\
Boletus & 39 & 3782 & Mycena & 51 & 6412 \\
Cortinarius & 36 & 4516 & Parasola & 6 & 2775 \\
Entoloma & 22 & 3188 & Pluteus & 19 & 3327 \\
Galerina & 12 & 3024 & Ramarıa & 6 & 2594 \\
Hericium & 4 & 2625 & Russula & 41 & 5140 \\
Hygrocybe & 16 & 3071 & Suillus & 19 & 2629 \\
Lactarius & 63 & 5902 & Trıcholoma & 30 & 4232 \\
\hline
\end{tabular}




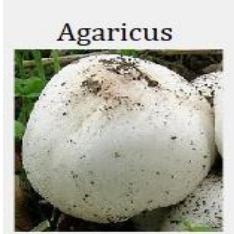

Hericium

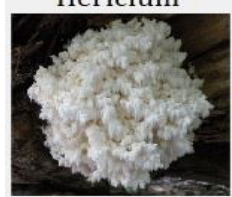

Parasola

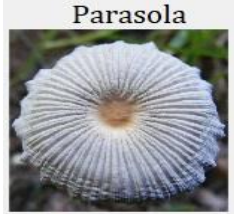

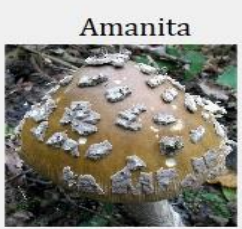

Hygrocybe

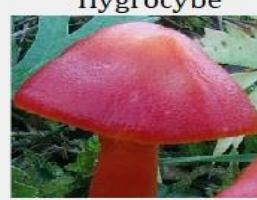

Pluteus

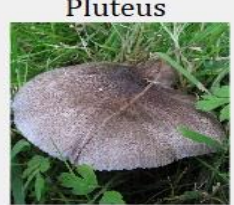

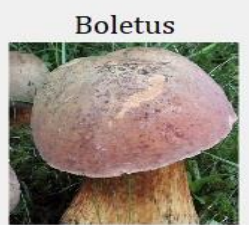

Lactarius

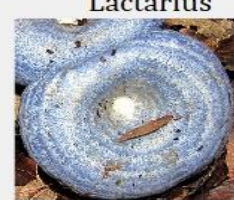

Ramaria

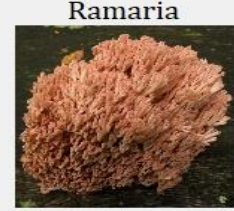

Şekil 17. Mantar aileleri șapka görüntü örnekleri.

\section{Bulgular}

Tanımlayıcı sistemler geliştirilirken karşılaşılan en büyük sorun güvenilir ve performans artırıcı veri setleri oluşturmaktır. Mevcut mantar veri setlerinde mantar görüntülerinden, mantar tanımlamayı zorlaştıran uzak mesafeden veya açıdan çekilmiş fotoğraflardır. Ayrıca kadraja çok fazla nesne ve bu nesnelere ait renk ve/veya desen girmesidir. Bu çalıșma için olușturulan veri setinde söz konusu sorunları ortadan kaldırmak amacıyla görüntüler kırpma ve kesme yöntemleriyle yeniden düzenlenmiştir. İncelenen diğer kaynaklar ve çekilen fotoğraflarla görüntü sayısı ve çeşitliliği artırılmıştır. Bunun yanı sıra yeni tanımlayıcı sistemler geliştirirken ortaya çıkan yaygın bir soru; veri setinin boyutunun ve eğitim verisinin veri setindeki oranının ne olduğudur. $\mathrm{Bu}$ soruyu yanıtlamak ve yukarıda belirtilen düzenlenmiş mantar görüntüleri ile mantar sayısı ve görüntü çeşitliliğinin tanımlama doğruluğu üzerinde etkisini deneysel olarak görmek amacıyla oluşturulan üç adet veri seti incelenmiştir.

Birinci veri seti; mevcut veri setleri, doğaseverlerin fotoğraf çekimleri ve çeşitli yayınlardan elde edilen görüntülerden oluşmaktadır. Görüntüler kaynaklardan alınarak düzenlenmeden oluşturulan veri setine eklenmiştir. Veri setindeki fotoğrafların birçoğunun mantar tanımlamaya katkıda bulunmak yerine tanımlamayı zora sokacak mesafeden veya açıdan çekilmesinin yanısıra kadraja çok fazla nesne ve bu nesnelere ait renk ve/veya desenin girmesidir. Şapka, Sap, Yüzük, Lamel ve Volva gibi mantar bölümlerinin renk, desen veya konumları görüntülerde ya arka planda kalmış ya da görüntüdeki diğer nesnelerin renk ve desenleri arasında belirleyici özelliklerini yitirmişlerdir. Şekil 18'deki grafikte de görülebileceği gibi bu veri seti ile eğitilen 6 adet önceden eğitilmiş ağın doğruluk oranı \%54.21 ile \%71.42 arasında değișmektedir.

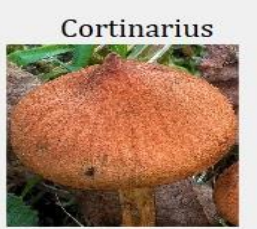

Lepiota

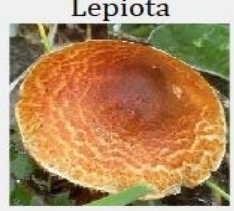

Russula

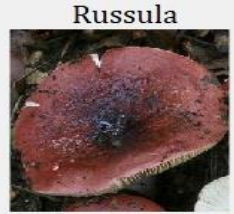

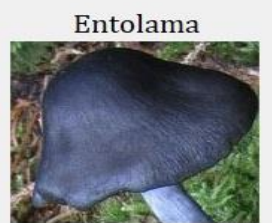

Lycoperdon

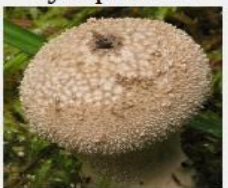

Suillus

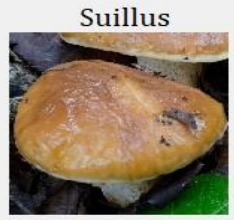

Galerina

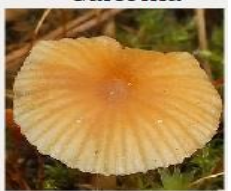

Mycena

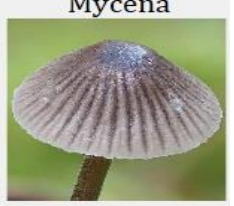

Tricholoma

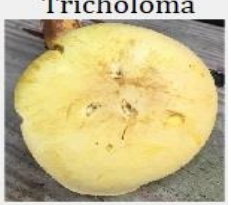

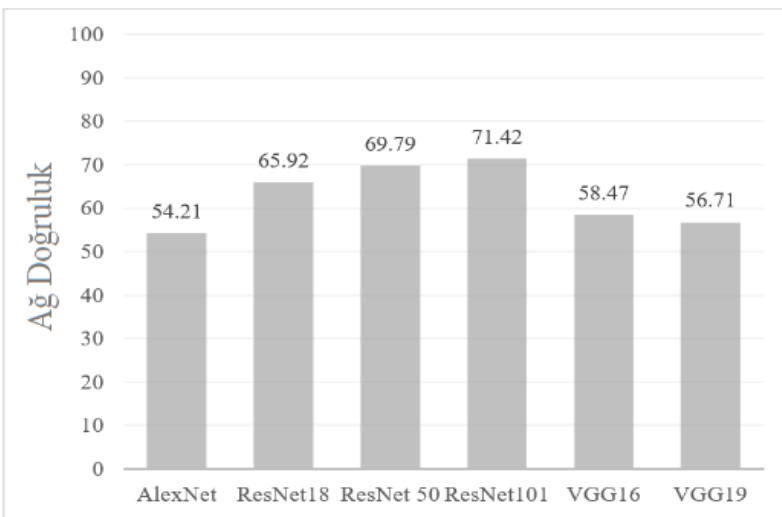

Șekil 18. Veri seti 1 ağ doğruluk oranları

İkinci veri seti; birinci veri setindeki görüntülerin kırpma ve kesme işlemiyle düzenlemiş Şapka, Lamel, Yüzük, Sap ve Volva bölümlerini içeren görüntülerden oluşmaktadır. Böylece birinci veri setindeki mantar dışındaki diğer nesneler çıkarılmıştır. Bunun sonucunda ikinci veri seti mantarların tanımlayıcı bölümlerini içeren bir veri seti haline gelmiştir. Söz konusu veri seti ile eğitilen ağların başarı oranı Şekil 19'da gösterildiği gibi \%69.75 ile \%84.14 arasında değișmektedir. Birinci veri setine göre başarı oranı ortalama $\% 15$ artmıștır.

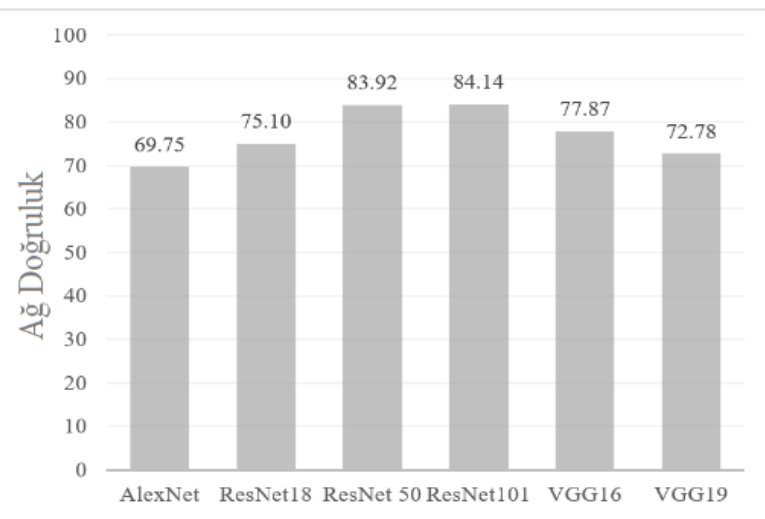

Şekil 19. Veri seti 2 ağ doğruluk oranları 
Üçüncü veri seti ise üzerindeki döküntü, leke, pul, kuşaklar, yivler, mantar türüne özgü desenler ve renkler bulunduran mantar şapkalarının ön planda olduğu düzenlenmiş görüntülerden oluşmaktadır. Özellikle zehirli olma ihtimali olan mantarlara dokunmadan ve mantarın fizik bütünlügüne zarar vermeden mantarların şapkalarını fotoğraflamak, mantarların diğer bölümlerini fotoğraflamaya göre daha kolay ve güvenilirdir. Mantar şapkasının diğer bölümlere göre daha fazla ayırt edici özellikler içermesi ve fotoğraflama kolaylığı bu veri setinin oluşturulmasında önemli rol oynamıştır. Söz konusu veri seti ile eğitilen ağların başarı oranı Şekil 20'de gösterildiği gibi $\% 80.05$ ile $\% 97.22$ arasında değişmektedir. Birinci veri setine göre başarı oranı ortalama $\% 25$, ikinci veri setine göre başarı oranı ortalama \%10 artmıştır.

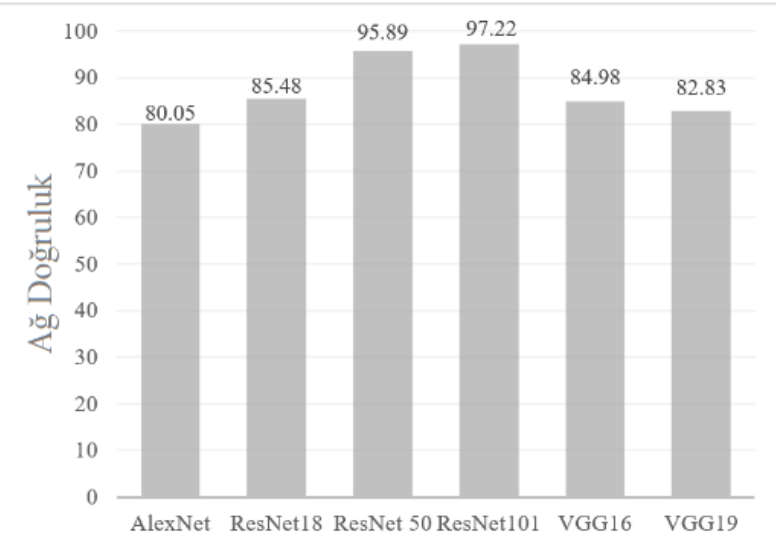

Şekil 20. Veri seti 3 ağ doğruluk oranları.

Mevcut veri setlerinden ve diğer kaynaklardan bir araya getirilerek oluşturulan Veri Seti 1 ile bu çalışma için oluşturulan Veri Seti 2 ve Veri Seti 3'ün tanımlama başarısını gösteren genel grafik Şekil 21 'de verilmiştir. Çalışmada kullanılan önceden eğitilmiş ağlardan ResNet101 ve ResNet50'nin düzenlenerek oluşturulan yeni veri setlerindeki başarısı kayda değer başarılardır. Bu iki ağın ağırlıklı olarak mantar şapkalarını içeren görüntülerden oluşan Veri Seti 3'deki başarısı ResNet101 için \%97.22 ve Resnet50 için \%95.89'dur.

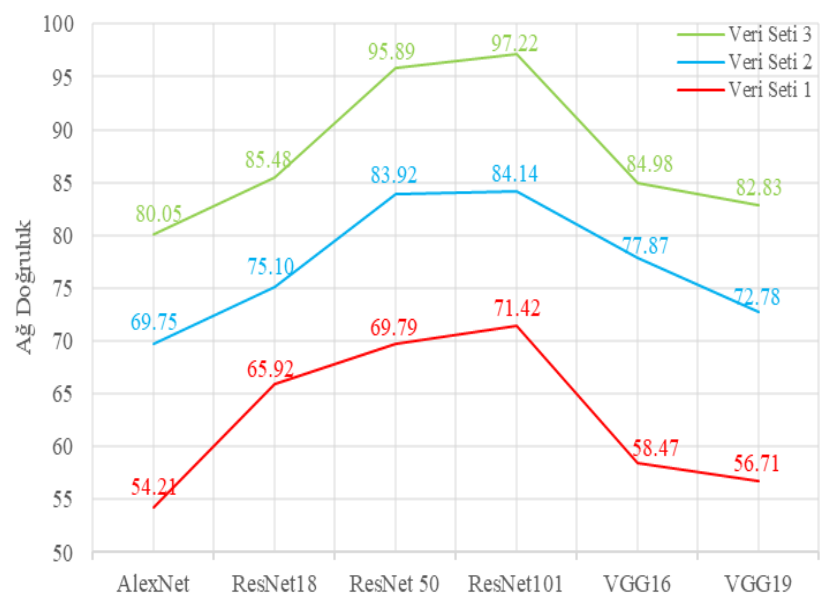

Şekil 21. Veri setleri ağ doğruluk oranları.
İncelenen ikinci konu ise eğitim verisi oranın ne olacağıdır. Bu amaçla en başarılı veri seti olan Veri Seti 3'te eğitim verisi oranı $\% 30, \% 50$ ve $\% 70$ alınarak ağlar eğitilmiștir. Eğitim verisi oranı \%30'dan \%70'e çıkarıldığında ağların doğruluk oranının \%3.26 ile \%5.16 arasında attığ gözlenmiștir. Her üç eğitim oranında da ResNet101 ve ResNet50 en başarılı ağlar olmuşlardır. Ayrıca başarı oranındaki en fazla artıș \%5.16 ve $\% 4.8$ ile bu ağlarda gerçekleşmiştir. Tablo 4 ve Şekil 22 'de bu değişimler gösterilmiştir.

Tablo 4. Veri seti 3 eğitim verisi oranı ağ doğruluk tablosu.

\begin{tabular}{cccc}
\hline A ğlar & $\% 30$ & $\% 50$ & $\% 70$ \\
\hline AlexNet & 75.40 & 76.67 & 80.05 \\
ResNet18 & 81.09 & 82.64 & 85.48 \\
ResNet 50 & 91.10 & 95.10 & 95.89 \\
ResNet101 & 92.06 & 94.82 & 97.22 \\
VGG16 & 80.30 & 81.88 & 84.98 \\
VgGG19 & 80.86 & 82.52 & 84.13 \\
\hline
\end{tabular}

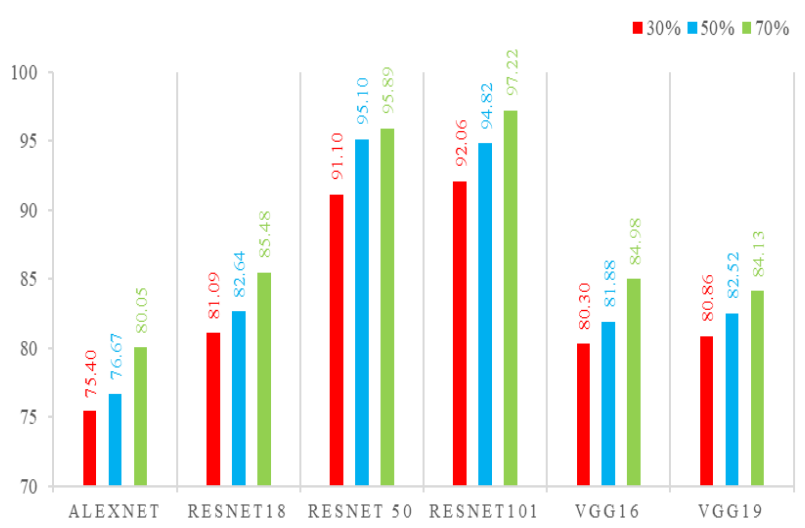

Şekil 22. Veri seti 3 eğitim verisi oranı-ağ doğruluk grafiği.

Veri Seti 3'te eğitim verisi oranı \%70 iken en başarılı ağ ResNet101'in Confusion Matrix'i ve bu matristen yola çıkılarak çizilen ROC grafiği ise Şekil 23'teki gibidir.

Çalışmada incelenen üçüncü konu; ağ katman sayısı, derinliği ve parametre sayısının tanımlama üzerindeki etkisidir. Veri Seti 3'te eğitim verisi oranı \%70 iken ağların katman, derinlik ve parametre sayısına bağlı olarak ağ doğruluk oranları da Tablo 5 ve Şekil 24'te verilmiştir.

Tablo 5. Katman, derinlik, parametre ve ağ doğruluk tablosu

\begin{tabular}{lcccc}
\multicolumn{1}{c}{ Ağlar } & Katman & Derinlik & $\begin{array}{c}\text { Parametre } \\
\text { (Milyon) }\end{array}$ & Doğruluk \\
\hline AlexNet & 25 & 8 & 61 & 80.05 \\
ResNet18 & 72 & 18 & 11.7 & 85.48 \\
ResNet50 & 177 & 50 & 25.6 & 95.89 \\
ResNet101 & 347 & 101 & 44.6 & 97.22 \\
VGG16 & 41 & 16 & 138 & 84.98 \\
VGG19 & 47 & 19 & 144 & 84.13 \\
\hline
\end{tabular}

Şekil 24'teki grafiklerde görüldüğü gibi ağ doğruluk oranlarındaki artış ile katman sayısı ve ağ derinliği doğru orantılıdır. 


\begin{tabular}{|c|c|c|c|c|c|c|c|c|c|c|c|c|c|c|c|c|c|c|}
\hline & 总 & 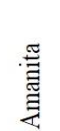 & $\frac{\mathscr{0}}{\frac{0}{0}}$ & 胥 & 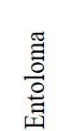 & 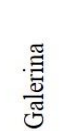 & 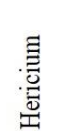 & 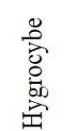 & 总 & 营 & 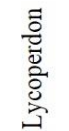 & 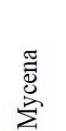 & $\begin{array}{l}\tilde{a} \\
0 \\
\tilde{a} \\
\tilde{\Xi} \\
\tilde{a}\end{array}$ & 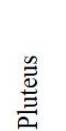 & 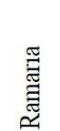 & 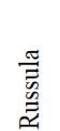 & 号 & 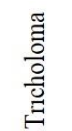 \\
\hline \multirow{11}{*}{$\begin{array}{l}\text { Agaricus } \\
\text { Amanita } \\
\text { Boletus } \\
\text { Cortinarius } \\
\text { Entoloma } \\
\text { Galerina } \\
\text { Hericium } \\
\text { Hygracybe } \\
\text { Lactarius } \\
\text { Lepiota } \\
\text { Lycoperdon }\end{array}$} & 0,97 & 0,00 & 0,00 & 0,00 & 0,00 & 0,00 & 0,00 & 0,00 & 0,00 & 0,00 & 0,00 & 0,00 & 0,00 & 0,01 & 0,00 & 0,00 & 0,00 & 0,02 \\
\hline & 0,00 & 0,97 & 0,00 & 0,00 & 0,00 & 0,00 & 0,00 & 0,00 & 0,00 & 0,01 & 0,00 & 0,00 &, 00 & 0,00 & 0,00 &, 00 & 0,00 & 07 \\
\hline & 0,00 & 0,00 & 1,00 & 0,00 & 0,00 & 0,00 & 0,00 & 0,00 & 0,00 & 0,00 & 0,00 & 0,00 & 0,00 & 0,00 & 0,00 & 0,00 & 0,00 & 0,00 \\
\hline & 0,00 & 0,00 & 0,00 & 0,96 & 0,00 & 0,00 & 0,00 & 0,00 & 0,00 & 0,00 & 0,00 & 0,00 &, 00 & 0,01 & 0,00 & 0,01 & 0,00 & 0,02 \\
\hline & 0,00 & 0,00 & 0,00 & 0,00 & 0,97 & 0,00 & 0,00 & 0,00 & 0,00 & 0,00 & 0,00 & 0,01 & 00 & 0,00 & 0,00 & 0,00 & 0,02 & 0,00 \\
\hline & 0,00 & 0,00 & 0,00 & 0,01 & 0,00 & 0,97 & 0,00 & 0,00 & 0,01 & 0,00 & 0,00 & 0,01 & 0,00 & 0,00 & 0,00 & 0,00 & 0,00 & 0,00 \\
\hline & 0,00 & 0,00 & 0,00 & 0,00 & 0,00 & 0,00 & 0,98 & 0,00 & 0,00 & 0,00 & 0,00 & 0,00 & 0,00 & 0,00 & 0,02 & 0,00 & 0,00 & 0,00 \\
\hline & 0,00 & 0,02 & 0,00 & 0,00 & 0,00 & 0,00 & 0,00 & 0,97 & 0,00 & 0,00 & 0,00 & 0,01 & 0,00 & 0,00 & 0,00 & 0,00 & 0,00 & 0,00 \\
\hline & 0,00 & 0,00 & 0,00 & 0,02 & 0,00 & 0,00 & 0,00 & 0,00 & 0,95 & 0,00 & 0,00 & 0,01 & 0,00 & 0,00 & 0,00 & 0,00 & 0,02 & 0,00 \\
\hline & 0,00 & 0,01 & 0,00 & 0,00 & 0,02 & 0,00 & 0,00 & 0,00 & 0,00 & 0,97 & 0,00 & 0,00 & 0,00 & 0,00 & 0,00 & 0,00 & 0,00 & 0,00 \\
\hline & 0,02 & 0,00 & 0,00 & 0,00 & 0,00 & 0,00 & 0,00 & 0,00 & 0,00 & 0,00 & 0,98 & 0,00 & 0,00 & 0,00 & 0,00 & 0,00 & 0,00 & 0,00 \\
\hline Mycena & 0,00 & 0,00 & 0,00 & 0,00 & 0,01 & 0,00 & 0,00 & 0,00 & 0,00 & 0,01 & 0,00 & 0,97 & 0,00 & 0,00 & 0,01 & 0,00 & 0,00 & 0,00 \\
\hline Parasola & 0,00 & 0,00 & 0,00 & 0,00 & 0,00 & 0,00 & 0,00 & 0,00 & 0,00 & 0,00 & 0,00 & 0,00 & 0,99 & 0,01 & 0,00 & 0,00 & 0,00 & 0,00 \\
\hline Pluteus & 0,00 & 0,00 & 0,00 & 0,00 & 0,00 & 0,01 & 0,00 & 0,00 & 0,00 & 0,02 & 0,00 & 0,01 & 0,00 & 0,96 & 0,00 & 0,00 & 0,00 & 0,00 \\
\hline Ramaria & 0,00 & 0,00 & 0,00 & 0,00 & 0,00 & 0,00 & 0,00 & 0,00 & 0,00 & 0,00 & 0,00 & 0,00 & 0,00 & 0,01 & 0,99 & 0,00 & 0,00 & 0,00 \\
\hline Russula & 0,01 & 0,00 & 0,00 & 0,02 & 0,00 & 0,00 & 0,00 & 0,00 & 0,00 & 0,01 & 0,00 & 0,00 & 0,00 & 0,00 & 0,00 & 0,96 & 0,00 & 0,00 \\
\hline & 0,00 & 0,00 & 0,00 & 0,01 & 0,00 & 0,00 & 0,00 & 0,00 & 0,01 & 0,00 & 0,00 & 0,00 & 00 & 0,00 & 0,00 & 0,00 & 0,98 & 0,00 \\
\hline alon & .02 & 00 & 0,00 & 01 & 0.00 & 0,00 & 0,00 & 0,00 & .00 & 0,00 & 0,00 & 0,00 & 0,00 & 0,00 & 0,00 & 01 & .00 & \\
\hline
\end{tabular}

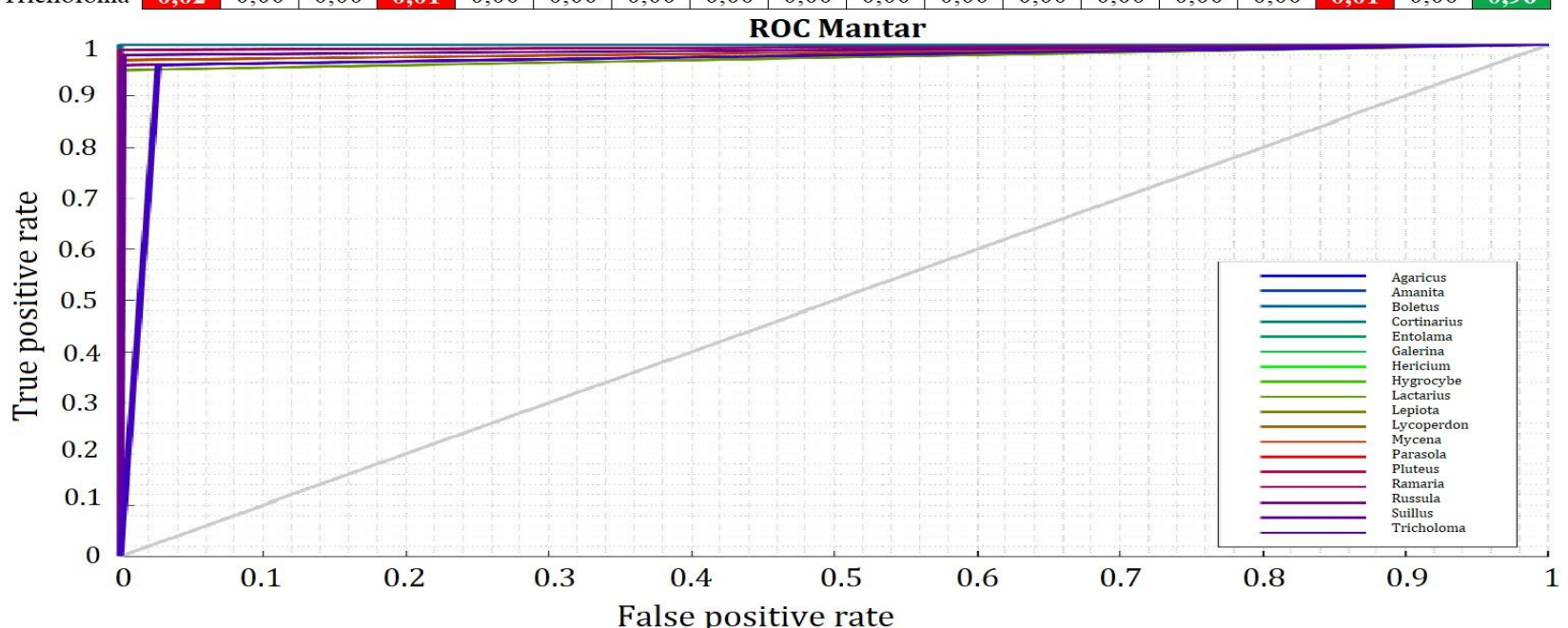

Şekil 23. Confusion matrisi ve ROC grafiği

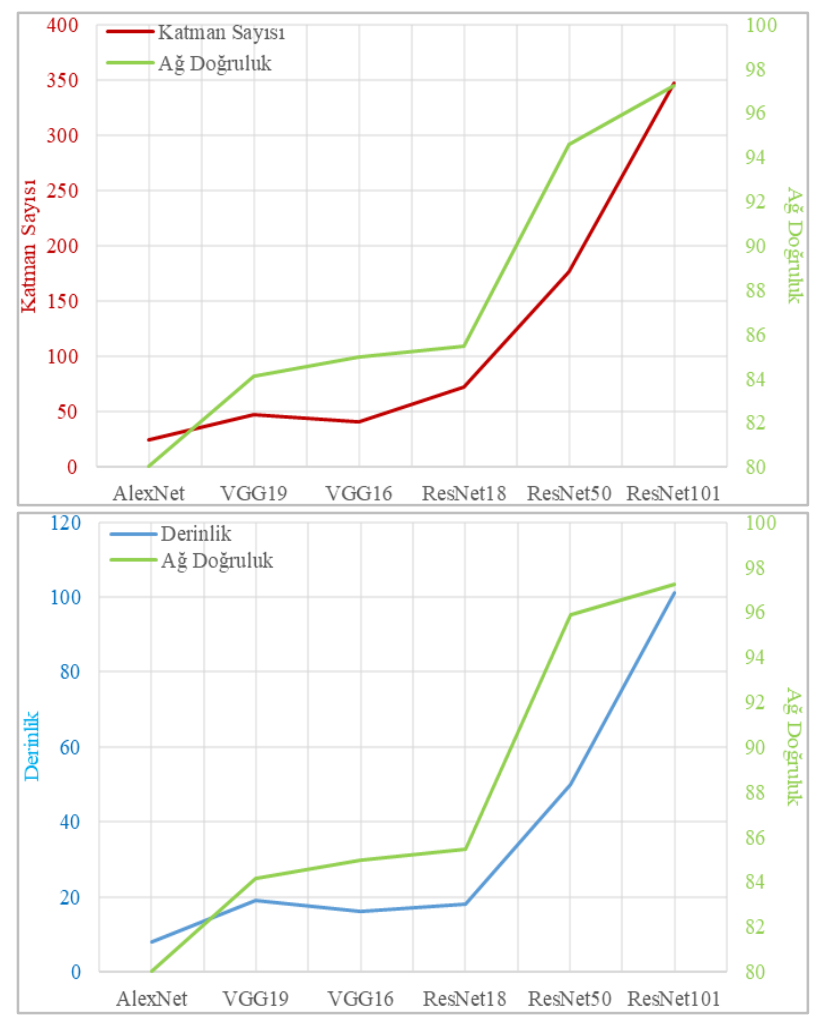

Şekil 24. Katman sayısı-ağ doğruluk ve derinlik-ağ doğruluk grafiği
Eğitimlerde elde edilen diğer bir sonuç; parametre sayısı az, önceden eğitilmiş ağların bu çalışmadaki gibi veri sayısı az, özel problemlere uygulandığında, genel eğilim ağ performanslarının parametre sayısı fazla ağlara göre daha iyi olduğudur. Söz konusu bu durum Tablo 5'teki değerlerle çizilen Şekil 25'te görülebilir.

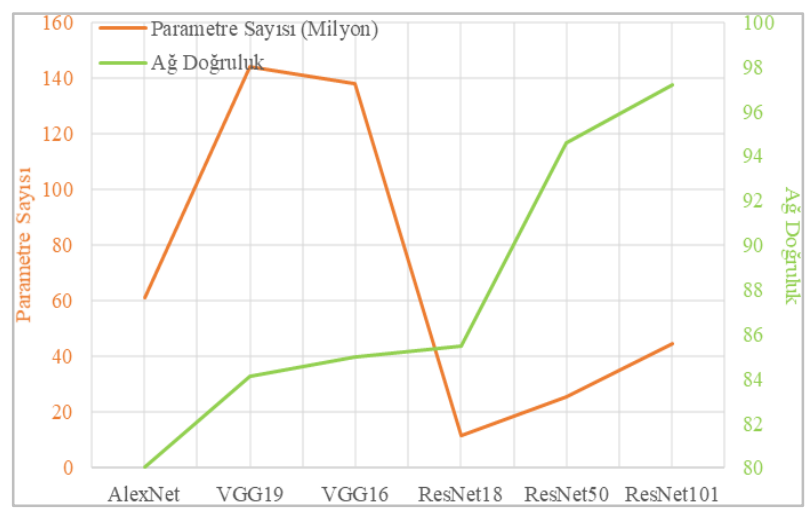

Şekil 25. Ağ parametre sayısı-ağ doğruluk grafiği

Çalışmada incelenen diğer bir konu ise düzenlileştirme etkisidir. Tablo 5 'teki sonuçlar parti büyüklüğü 32 alınarak elde edilmiş sonuçlardır. Düzenlileştirme etkisini değerlendirmek amacıyla 
Tablo 5'teki en başarılı iki ağ ResNet50 ve ResNet101 parti büyüklükleri 8,16 ve 64 olacak şekilde yeniden eğitilerek test edilmiştir. Eğitimler üçüncü veri setinde yapılmış ve eğitim verisi oranı $\% 70$ alınmıştır. Eğitim sonuçları Tablo 6 ve Şekil 26'da verilmiştir.

Tablo 6. Parti büyüklüğü-ağ doğruluk tablosu

\begin{tabular}{ccc}
\hline \multirow{2}{*}{ Parti Büyüklüğü } & \multicolumn{2}{c}{ A ̆ Doğruluk } \\
\cline { 2 - 3 } & ResNet50 & ResNet101 \\
\hline 8 & 97.44 & 97.62 \\
16 & 95.40 & 95.91 \\
32 & 95.89 & 97.22 \\
64 & 95.48 & 94.75 \\
\hline
\end{tabular}

Elde edilen sonuçlar parti büyüklüğünün (Batch Size) 8 olması durumunda ağ performanslarının daha iyi olacağı yönündedir. Parti büyüklüğünün 8 olması durumunda en başarılı iki ağdan ResNet50'nin başarı oranı \%95.89'dan \%97.44'e, ResNet101'in başarı oranı \%97.22'den \%97.62'ye çıkmıştır.

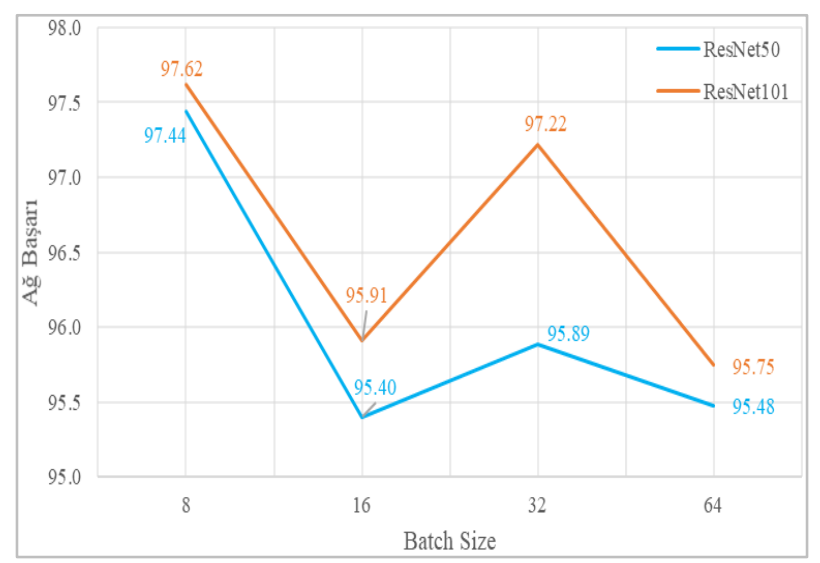

Şekil 26. Parti büyüklüğü-ağ doğruluk grafiği

\section{Tartışma ve Sonuç}

$\mathrm{Bu}$ çalışmayla önceden eğitilmiş ağlarda transfer öğrenme yöntemi kullanılarak mantar görüntülerinden mantar türü tanımlanmasının yüksek başarı oranı ile yapılabileceği gösterilmiştir. $\mathrm{Bu}$ sonuç; probleme, veriye ve ağa uygun transfer öğrenme yöntemi seçildiğinde önceden eğitilmiş ağların bu ve benzeri problemlere iyi çözümler getireceğini göstermesi açısından önemlidir. Çalışmanın diğer önemli bir sonucu, üzerinde birçok tanımlayıcı özellik taşıyan mantar şapkasının mantar tanımlamada çok önemli rol oynadığını göstermesidir. Ayrıca, bir mantardan çok sayıda fotoğraf çekmek yerine, çok sayıda mantardan fotoğraf çekmenin ağ performansı açısından çok daha önemli olduğunu sonucuna varılmıştır.

Gerek mevcut veriler gerekse düzenlenerek oluşturulan yeni veri setinde oldukça yüksek başarı gösteren ve ileriye dönük iyi bir çözüm olduğunu ispatlayan bu görsel tür tanımlaması; mantarların geleceğe taşınmasında, hayatî açıdan önemli; mantarların koruma altına alınmasında, mantar kaynaklarının sürdürülebilir yönetim planlarının yapılmasında, zehirli mantarların tespitinde, mantar yetiştiriciliğinde, mantar toplayıcıların mantarları türlerine göre sınıflandırılmasında yararlı olabilecek bir problem çözümüdür.

$\mathrm{Bu}$ çalışmanın temel amaçlarından biri, mantar görüntülerinden mantar türlerinin tanımında karşılaşılan veri kümesinin eksikliğine veya yetersizliği sorununun çözümüne katkıda bulunmaktır. Fakat yeryüzündeki mantar sayısı ve bulundukları ortam çeşitliliği düşünüldüğünde veri setini büyütmek tek kişilik bir çalışmadan çok uzak bir ekip işidir ve uzun yllar devam edecek bir süreçtir. Bu çalışma sonrasında; Türkiye'deki mantar türlerini kapsayan bir projeyle çalışmanın geliştirilmesi ve kamuya açılması planlanmaktadır.

Veri seti oluşturulurken diğer taraftan ağ eğitimleri ile aile ve sınıf tanımlamaları gerçekleștirilmiş böylece çalışmanın performansı sürekli denetlenmiştir. Veri seti toplanırken aynı aileye yeni mantar sinıfları eklendikçe şapka renk ve desen benzerliğinin arttığı gözlenmiştir. Bu durum aynı aile içerisindeki sınıf tanımlamayı zamanla düşürmüş, bir süre sonra ise aile tanımlamayı da etkilediği gözlenmiştir. $\mathrm{Bu}$ problemin çözümü için, giriş katmanını yüksek görüntü çözünürlüğüne göre tasarlamak iyi bir yaklaşım olacaktır. Çalışmada kullanılan ağların katman sayısı ve derinliği arttıkça ağ başarı oranı artmıştır. Ağ parametre sayısı arttıkça da başarı oranının düştüğü gözlenmiştir. Veri boyutunun ağ parametre sayısına göre çok küçük kalması bu sonuca neden olmuştur. Ayrıca parti büyüklüğünün ağ başarı oranını etkilediği gözlenmiştir. $\mathrm{Bu}$ sonuçlar transfer öğrenme yönteminin kullanıldığı problem çözümlerinde dikkat edilecek hususlardır. Çalışmada yüksek performans gösteren ağlar referans alınarak ve çalışma esnasında kazanılan tecrübeler ile planlanan proje kapsamındaki yeni ağ tasarımında kullanılacaktır. Planlanan bu çalışmada hedeflenen sadece aile tanımlaması değil sınıf tanımlaması yapabilen ağ tasarlamaktır.

\section{Etik Beyanı}

Bu çalışmada, "Yükseköğretim Kurumları Bilimsel Araştırma ve Yayın Etiği Yönergesi" kapsamında uyulması gerekli tüm kurallara uyulduğunu, bahsi geçen yönergenin "Bilimsel Araştırma ve Yayın Etiğine Aykırı Eylemler" başlığı altında belirtilen eylemlerden hiçbirinin gerçekleştirilmediğini taahhüt ederiz.

\section{Kaynakça}

[1] Zhang, M., Cui, S. W., Cheung, P. C. K., Wang, Q. 2007. Antitumor polysaccharides from mushrooms: a review on their isolation process, structural characteristics and antitumor activity. Trends in Food Science \& Technology, 18(1), 419. 
[2] Cheung, P. C. K. 2013. Mini-review on edible mushrooms as source of dietary fiber: Preparation and health benefits. Food Science and Human Wellness, 2, 162-166.

[3] Feeney, M. J., Miller, A. M., Roupas, P. 2014. Mushrooms-Biologically Distinct and Nutritionally Unique: Exploring a Third Food Kingdom. Nutrition Today, 49(6), 301-307.

[4] Valentao, P., Andrade, P. B., Rangel, J., Ribeiro, B., Silva, M. B., Baptista, P., Seabra, R. M. 2005. Effect of The Conservation Procedure on the Contents of Phenolic Compounds and Organic Acids in Chanterelle (Cantharellus cibarius) Mushroom. Journal of Agricultural and Food Chemistry, 53, 4925-4931.

[5] Mithril, C., Dragsted, L. O., Meyer, C., Tetens, I., Biltoft-Jensen, A., Astrup, A. 2013. Dietary composition and nutrient content of the New Nordic Diet. Public Health Nutrition, 16(5), 777785.

[6] Kalac, P. 2013. A review of chemical composition and nutritional value of wildgrowing and cultivated mushrooms. Journal of the Science of Food and Agriculture, 93, 209-218.

[7] Athanasakis, G., Aligiannis, N., Zagou, Z. G., Skaltsounis, A. L., Fokialakis, N. 2013. Antioxidant properties of the wild edible mushroom Lactarius salmonicolor. Journal of Medicinal Food, 16(8), 760-764.

[8] Heleno, S. A., Barros, L., Sousa, M. J., Martins, A., Ferreira, I. C. F. R. 2009. Study and Characterization of Selected Nutrients in Wild Mushrooms from Portugal by Gas Chromatography and High Performance Liquid Chromatography. Microchemical Journal, 93, 195-199.

[9] Wang, Y., Hall, R. 2004. Edible ectomycorrhizal mushrooms: challenges and achievements. Canadian Journal Botany, 82(8), 1063-1073.

[10] Chang, S. T. 1999. World Production of Cultivated Edible and Medicinal Mushrooms in 1997 With Emphasis on Lentinus edodes (Berk.) Sing, in China. International Journal of Medicinal Mushrooms, 1, 291-300.

[11] Boa, E. 2004. Wild Edible Fungi a Global Overview of Their Use and Importance to People. Fao Press, Rome, 150s.

[12] Kalac, P. 2009. Chemical Composition and Nutritional Value of European Species of Wild Growing Mushrooms: A Review. Food Chemistry, 113, 9-16.

[13] Chang, S. T., Miles, P. G. 2004. Mushrooms: Cultivation, Nutritional Value, Medicinal Effect, and Environmental Impact. 2nd edition. CRC Press, Boca Raton, 431s.
[14] Food and Agriculture Organization of the United Nations. World Food and Agriculture-Statistical Pocketbook 2018. http://www.fao.org/3/CA1796EN/ca1796en.pd f (Erişim Tarihi: 11.09.2019).

[15] Zion Market Research. Global Mushroom Industry Size \& Analysis Report, 2015-2021 by Market.https://www.zionmarketresearch.com/r eport/mushroom-market (Erişim Tarihi: 10.12.2019).

[16] Mushroom observer. https://mushroomobserver.org/ (Erişim Tarihi:12.12.2019).

[17] GitHub. 2018 FGVCx Fungi Classification Challenge.https://github.com/visipedia/fgvcx_f ungi_comp (Erişim Tarihi:10.07.2019).

[18] Danmarks svampeatlas. https://svampe.databasen.org/ (Erişim Tarihi:10.07.2019).

[19] Kaggle. Mushrooms classification-Common genus's images. https://www.kaggle.com/maysee/mushroomsclassification-common-genuss-images (Erişim Tarihi: 21.07.2019).

[20] Goeau, H., Bonnet, P., Joly, A., Bakic, V., Barthélémy, D., Boujemaa, N., Molino, J. F. 2013. The imageclef 2013 plant identification task, 2326 September, Valencia, Spain.

[21] Goeau, H., Joly, A., Bonnet, P., Selmi, S., Molino, J. F., Barth'el'emy, D., Boujemaa, N. 2014. Lifeclef plant identification task 2014. Working Notes for CLEF 2014 Conference, 15-18 September, Sheffield, United Kingdom, 598-615.

[22] Lowe, D. G. 1990. Object recognition from local scale-invariant features. The proceedings of the seventh IEEE international conference on Computer vision, 2, 1150-1157.

[23] Bay, H., Tuytelaars, T., Van, G. L. 2006. Surf: Speeded up robust features. 9th European Conference on Computer Vision, 7-13 May, Graz, Austria, 404-417.

[24] Ojala, T., Pietikäinen, M., Harwood, D. 1996. A comparative study of texture measures with classification based on featured distributions. Pattern recognition, 29(1), 51-59.

[25] Goëau, H., Bonnet, P., Joly, A. 2015. LifeCLEF plant identification task 2015. LifeCLEF 2015: Multimedia Life Species Identification Challenges, 8-11 September, Toulouse, France.

[26] Šulc, M., Mishkin, D., Matas, J. 2016. Very deep residual networks with maxout for plant identification in the wild. Conference Working notes of CLEF 2016, 5-8 September, Evora, Portugal. 
[27] Sunderhauf, N., McCool, C., Upcroft, B., Tristan, P. 2014. Fine-grained plant classification using convolutional neural networks for feature extraction. Working notes of CLEF 2014 Conference, 15-18 September, Sheffield, United Kingdom, 756-762.

[28] Champ, J., Lorieul, T., Servajean, M., Joly, A. 2015. A comparative study of fine-grained classification methods in the context of the LifeCLEF plant identification challenge 2015. in CEUR Workshop Proceedings, 8-11 September, Toulouse, France, 1391.

[29] Goëau, H., Bonnet, P., Joly, A. 2017. Plant identification based on noisy web data: the amazing performance of deep learning. Working notes of CLEF 2017 Conference, 11-14 September, Dublin, Ireland.

[30] Masoudian, A., Kenneth, A. M. 2013. Application of support vector machine to detect microbial spoilage of mushrooms. 2013 International Conference on Computer and Robot Vision, 2831 May, Regina, Canada, 281-287.

[31] Subramaniam, A., Oh, B. J. 2016 Mushroom Recognition Using PCA Algorithm. International Journal of Software Engineering and Its Applications, 10(1), 43-50.

[32] Kim, K. J., Jung, S. H., So, W. H., Sim, C. B. 2017. A Study on Mushroom Pest and Diseases Analysis System Implementation based on Convolutional Neural Networks for Smart Farm. International Journal of Control and Automation, 10(11), 6172.

[33] Olpin, A. J. 2018. Convolutional Networks for Segmentation and Detection of Agricultural Mushrooms. MSc Thesis, University of Guelph, Ontario, Canada.

[34] Rahmat, R. F., Aruan, T., Purnamawati, S., Faza, S., Lini T. Z. 2018. Fungus image identification using K-Nearest Neighbor. IOP Conference Series Materials Science and Engineering, 19-20 July, Medan, Indonesia, 420(1).

[35] Wibowo, A., Rahayu, Y., Riyanto, A., Hidayatulloh, T. 2018. Classification Algorithm for Edible Mushroom Identification. 2018 International Conference on Information and Communications Technology, 6-7 March, Yogyakarta, Indonesia.

[36] Wulandari, M., Kusumaningtyas, E. M., Politeknik A. R. B. 2018. Identification of Poisonous Fungi Basidiomycota Macro Based on Mobile Device Using Neural Network. 2018 International Electronics Symposium on Knowledge Creation and Intelligent Computing, 29-30 October, Bali, Indonesia.

[37] Anil, A., Gupta, H., Arora, M. 2019. Computer vision based method for identification of freshness in mushrooms. 2019 International
Conference on Issues and Challenges in Intelligent Computing Technique, 27-28 September, Ghazlabad, India.

[38] Maurya, P., Singh, N. P. 2020. Mushroom Classification Using Feature-Based Machine Learning Approach. Proceedings of 3rd International Conference on Computer Vision and Image Processing, 197-206.

[39] Gürkan, H., Hanilçi, A. 2020. Evrişimli sinir ağı ve QRS imgeleri kullanarak EKG tabanlı biyometrik tanıma yöntemi. Pamukkale Üniversitesi Mühendislik Bilimleri Dergisi, 26(2), 318-327.

[40] Goodfellow, I., Bengio, Y., Courville, A. 2015. Deep Learning. The MIT Press, Cambridge, Massachusetts, United States, 848s.

[41] Indolia, S., Goswami, A. K., Mishra, S. P., Asopa, P. 2018. Conceptual Understanding of Convolutional Neural Network-A Deep Learning Approach. Procedia Computer Science, 132, 679688.

[42] Nebauer, C. 1998. Evaluation of convolutional neural networks for visual recognition. IEEE Transactions on Neural Networks, 9(4), 685696.

[43] Yamashita, R., Nishio, M., Do, R. K. G., Togashi, K. 2018. Convolutional neural networks: an overview and application in radiology. Insights Imaging, 9, 611-629.

[44] Lawrence, S., Giles, C. L., Tsoi, A. C., Back, A. D. 1997. Face recognition: A convolutional neuralnetwork approach. IEEE Transactions on Neural Networks, 8(1), 98-113.

[45] MathWorks. Learn About Convolutional Neural Networks.https://www.mathworks.com/help/d eeplearning/ug/introduction-to-convolutionalneural-networks.html (Erişim Tarihi: 26.11.2019).

[46] Baykal E, Doğan H, Ercin ME, Ersoz S, Ekinci M. Transfer learning with pre-trained deep convolutional neural networks for serous cell classification. Multimedia Tools and Applications, 1-19, 2019.

[47] Zhou, Y., Nejati, H., Do, T. T., Cheung, N. M., Cheah, L. 2016. Image-based vehicle analysis using deep neural network: A systematic study. IEEE international conference on digital signal processing, 276-280.

[48] He, K., Zhang, X., Ren, S., Sun, J. 2016. Deep Residual Learning for Image Recognition. IEEE Conference on Computer Vision and Pattern Recognition, Las Vegas, United States, 770-778.

[49] Theckedath, D., Sedamkar, R. R. 2020. Detecting Affect States Using VGG16, ResNet50 and SE-ResNet50 Networks. Springer Nature Computer Science, 79, 1-7. 
[50] Ye, H., Han, H., Zhu, L., Duan, Q. 2019. Vegetable pest image recognition method based on improved VGG convolution neural network. Journal of Physics: Conference Series, 1237(3).

[51] Leo F. Isikdogan, https://www.isikdogan.com/ (Erişim Tarihi:12.12.2020).

[52] Nova Research Lab, https://medium.com/novaresearchlab/\%C3\%B 6\%C4\%9Frenme-aktar\%C4\%B1m\%C4\%B1transfer-learning-c0b8126965c4 (Erişim Tarihi:12.12.2019)

[53] Pan, S. J., Yang, Q. 2010. A survey on transfer learning. IEEE Transactions on Knowledge and Data Engineering, 22(10), 1345-1359.

[54] Chollet, F. 2017. Deep Learning with Python. Manning Publications, New York, United States, 400s.

[55] Machine Learning Mastery. A Gentle Introduction to Transfer Learning for Deep Learning.https://machinelearningmastery.com/ transfer-learning-for-deep-learning/ (Erişim Tarihi: 10.12.2019).

[56] Martinez, J.B., Gill, G. 2019. Comparison of Pretrained vs Domain-specific Convolutional Neural Networks for Classification of Interstitial Lung Disease, 2019 International Conference on Computational Science and Computational Intelligence (CSCI), 991-994, 5-7 December, Las Vegas, NV, USA.

[57] First Nature. Fungi Identification-Picture Galleries. https://www.firstnature.com/fungi/index1binom.php (Erişim Tarihi: 06.01.2020).

[58] Mushroom World. Mushrooms-Alphabetical list. http://www.mushroom.world/mushrooms/na melist (Erişim Tarihi:10.11.2019).

[59] Eyssartier, G., Roux, P. 2011. Le Guide Des Champignons. Belin, Paris, France, 1095s.

[60] Borgarino, D., Hurtado, C., Lagier, R. 2016. Le Guide Des Champignons. Edisud, France, 452. 